\title{
MODIFIED NANOPARTICLE OXIDES FOR FINAL POLISHING OF METALS
}

\author{
L. F. Koroleva \\ Institute of Engineering Science, Ural Branch of the Russian Academy of Sciences, 34 Komsomolskaya st., \\ Ekaterinburg, Russian Federation \\ *Corresponding author. E-mail: lq@imach.uran.ru; address for correspondence: 34, ul. Komsomolskaya,
620049, Ekaterinburg, Russian Federation. Tel.: +7 343 3741853; fax: +7 3433745330
}

A concept of mechanochemical final polishing of hardened steels and non-ferrous metals with nanodispersed abrasive materials is discussed. It has been found that the solid solution of aluminum and iron oxides based on corundum and hematite, $\mathrm{Al}_{2-\mathrm{x}} \mathrm{Fe}_{\mathrm{x}} \mathrm{O}_{3}$ and $\mathrm{Fe}_{2-\mathrm{y}} \mathrm{Al}_{\mathrm{y}} \mathrm{O}_{3}$, which is derived from hydroxocomplexes, is tribochemically active, provides high productivity and nanoroughened surface $\left(R_{a} 0.002\right.$ to $\left.0.005 \mu \mathrm{m}\right)$ in the processes of final polishing of ShKh15-type steels with austenitic-martensitic structure, as well as copper, aluminum and titanium and their alloys. The modification of the solid solution of aluminum and iron oxides with molybdenum, manganese and zirconium oxides provides a nanoroughened surface of non-ferrous metals in the processes of final polishing.

Keywords: modification, solid solutions, oxides, final polishing, mechanochemistry.

DOI: $10.17804 / 2410-9908.2016 .2 .048-073$

\section{References}

1. Artemov A.S. Polishing nanodiamonds. Physics of the Solid State, 2004, vol. 46, iss. 4, pp. 687-695. DOI: 10.1134/1.1711453.

2. Jackson M.J., Mills B., Hitchiner M.P. Controlled wear of vitrified abrasive materials for precision grinding applications. Sadhana, 2003, vol. 28, no. 5, pp. 897-914. DOI: $10.1007 / \mathrm{BF} 02703320$.

3. Bakharev V.P. Dispersion of Ceramics and Composites in Diamond Finishing by Free Abrasive. Russian Engineering Research, 2009, vol. 29, no 2, pp. 162-168. DOI: 10.3103/S1068798X09020129.

4. $\quad$ Filatov Yu.D., Yashchuk V.P., Heisel U., Storchak M., Monteil G. Assessment of surface roughness and reflectance of nonmetallic products upon diamond abrasive finishing. Journal of Superhard Materials, vol. 31, no. 5, pp. 338-346. DOI: 10.3103/S1063457609050098.

5. Storozhenko P.A., Guseinov S.L., Malashin S.I. Nanodispersed powders: Synthesis methods and practical applications. Nanotechnologies in Russia, 2009, vol. 4, iss. 5, pp. 27-39. DOI: $10.1134 /$ S1995078009050024.

6. Pokropivnyi V.V, Silenko P.M. Silicon carbide nanotubes and nanotubular fibers: Synthesis, stability, structure, and classification. Theoretical and Experimental Chemistry, 2006, vol. 42, iss. 1, pp. 3-15. DOI: 10.1007/s11237-006-0010-y.

7. Khanra A.K. Production of boron carbide powder by carbothermal synthesis of gel material. Bulletin of Materials Science, 2007, vol. 30, iss. 2, pp. 93-96. DOI: 10.1007/s12034-007-0016-7.

8. Bogdanov S.P. Influence of superstoichiometric boron on the Synthesis of cubic Boron nitride. Glass Physics and Chemistry, 2008, vol. 34, no. 3, pp. 336-339. DOI: $10.1134 / \mathrm{S} 108765960802017 \mathrm{X}$.

9. Garshin A.P., Gropyanov V.M., Lagunov Yu.V. Abrazivnye materialy [Abrasive Materials]. L., Mashinostroenie Publ., 1983, 230 p. (In Russian).

10. Viktorov V.V., Fotiev A.A., Badich V.D. Abrasive and thermal properties of $\mathrm{Al}_{2} \mathrm{O}_{3}-\mathrm{Cr}_{2} \mathrm{O}_{3}$ solid solutions. Inorganic Materials, 1996, vol. 32, iss. 1, pp. 55-57. 
11. Chekhomova L.F. Abrasive Properties of Modified Chromia. Inorganic Materials, 2001, vol. 37, no. 3, pp. 274-280. DOI: 10.1023/A:1004173632509. - ISSN 0020-1685.

12. Chekhomova L.F. Abrasive properties of aluminum iron oxide nanoparticles. Inorganic Materials, 2009, vol. 45., no. 10, pp. 1158-1165. DOI: 10.1134/S0020168509100148.

13. Khodakov G.S. Physicochemical mechanics of the technology of material processing. Ros. khim. zhurnal im. D.I.Mendeleeva, 2000, no. 3, pp. 93-107. (In Russian).

14. Marchenko E.A., Kharach G.M. On the mechanisms of microcracking in the surface layers of metals under conditions of friction in plastic contact. Doklady Akademii nauk. Tekhnicheskaya fizika, 1976, vol. 231, no. 4, pp. 853-855. (In Russian).

15. Yashcheritsyn P.I., Martynov A.N. Chistovaya obrabotka detaley v mashinostroenii [Finishing of Machine Parts in Mechanical Engineering]. Minsk, Vysheisha Shkola Publ., 1983, 191 p. (In Russian).

16. Kubashevsky O., Gopkins B. Okislenie metallov i splavov [Oxidation of Metals and Alloys]. M., Metallurgiya Publ., 1965, 428 p. (In Russian).

17. Bastawtos A.F., Chandra A., Guo Y., Yan B. Pad effects on material-removal rate in chemical-mechanical planarization. Journal of Electronic Materials, 2002, vol. 31, no. 10, pp. 1022-1031. DOI: 10.1007/s11664-002-0038-2.

18. Tseng W-T., Wang Y-H. and Chin J-H. Effects of film stress on the chemical mechanical polishing process. Journal of the Electrochemical Society, 1999, vol. 146, no. 11, pp. 4273-4280.

19. $\mathrm{Fu}$ G., Chandra A. A model for wafer scale variation of material removal rate in chemical mechanical polishing based on viscoelastic pad deformation. Journal of Electronic Materials, 2002, vol. 31, no. 10, pp. 1066-1073. DOI: 10.1007/s11664-002-0044-4.

20. Fu G., Chandra A. A model for wafer scale variation of removal rate in chemical mechanical polishing based on elastic pad deformation. Journal of the Electronic Materials, 2001, vol. 30, no. 4, pp. 400-408. DOI: 10.1007/s11664-001-0051-X.

21. Wang Y.G., Zhao Y.W., Li X. Modeling the effects of abrasive size, surface oxidizer and binding energy on chemical mechanical polishing at molecular scale. Tribology International, 2008, vol. 41, pp. 202-210. DOI: 10.1016/J.Triboint.2007.08.004.

22. Heinike G. Tribokhimiya [Tribochemistry]. M., Mir Publ., 1987, 582 p. (In Russian).

23. Rebinder P.A. The Significance of Physicochemical Processes in Mechanical Failure and Processing of Solids in Engineering. Vestnik AN SSSR, 1940, no. 8, pp. 5-28. (In Russian).

24. Likhtman I., Shchukin E.D., Rebinder P.A. Fiziko-khimicheskaya mekhanika metallov [Physicochemical Mechanics of Metals]. M., Izd. AN SSSR Publ., 1962, 303 p. (In Russian).

25. Mamonova M.V., Prudnikov V.V., Prudnikova I.A. Fizika poverkhnosti. Teoreticheskie modeli $i$ eksperimentalnye metody [Surface Physics. Theoretical Models and Experimental Methods]. M., Fizmatlit Publ., 2011, 400 p. ISBN 978-5-9221-1236-9. (In Russian).

26. Tonkie plenki. Vzaimnaya diffuziya i reaktsii [Thin films. Interdiffusion and Reactions]. J.M. Poate, K.N. Tu and J.W. Mayer, eds. M., Mir Publ., 1982, 575 p. (In Russian).

27. Cabrera N. The oxidation of metals In: Semiconductor surface physics. Philadelphia, Univ. of Pennsylvania Press, 1956, pp. 327-332.

28. Mott N. The theory of protective films formation on the metal surface. In: Trans. Faraday Soc., 1949, vol. 40, pp. 472-486.

29. Koroleva L.F. Final Polishing of Metals to Obtain Nanoroughened Surface. Nanotechnologies in Russia, 2012, vol. 7, nos. 1-2, pp. 67-75. DOI: 10.1134/S1995078012010119. ISSN: 1995-0780.

30. Boldyrev V.V. Reaktsionnaya sposobnost tverdykh veshchestv (na primere reaktsii termicheskogo razlozheniya) [Reactivity of Solid Substances (Exemplified by the Reaction of Thermal Decomposition]. Novosibirsk, Izd. SO RAN Publ., 1997, 304 p. (In Russian).

31. Sakovich G.V., Chizhova N.P. Temperature dependence of the rate of thermal expansion of potassium bicarbonate. Izv. VUZov. Khimiya $i$ khim. tekhnologiya, 1961, no. 5, pp. 747-750. (In Russian). 
32. Kim Jin-seob, Lim Eun-seong, Jung Yoon-gyo. Determination of efficient superfinishing conditions for mirror surface finishing of titanium. J. Cent. South Univ., 2012, vol. 19, pp. 155-162. DOI: 10.1007/s11771-012-0985-6. ISSN: 2095-2899.

33. Kotov Yu.A., Samatov O.M. Characteristics of aluminum oxide powders produced by impulse wire heating. Poverkhnost, 1994, nos. 10-14, pp. 90-94. (In Russian).

34. Safronov A.P., Kalinina E.G., Blagodetelev D.A., Kotov Y.A. Separation of aluminum oxide powders with different degrees of aggregation by sedimentation in an aqueous medium. Nanotechnologies in Russia, 2010, vol. 5, iss. 7-8, pp. 498-505. DOI: 10.1134/S1995078010070104.

35. Silyakov L., Pesotskaya N.S., Yukhvid V.I. Self-distributing high-temperature synthesis and the properties of a corundum-based abrasive composite material. Neorganicheskie materialy, 1995, vol. 31, no. 3, pp. 351-357. (In Russian).

36. Tarasov A.G., Gorshkov V.A., Yukhvid V. Phase composition and microstructure of $\mathrm{Al}_{2} \mathrm{O}_{3}$ $\mathrm{Cr}_{2} \mathrm{O}_{3}$ solid solutions prepared by self-propagating high-temperature synthesis. Inorganic Materials, vol. 43, iss. 7, pp. 724-728. DOI: 10.1134/S0020168507070102.

37. Belousov V.M., Chertov V.M., Rozhkova E.V., Litvin V.I., Zazhigalov V.A. A sol-gel method for synthesizing porous iron-aluminum oxide substances and regulating their physicochemical characteristics. Theoretical and Experimental Chemistry, 1997, vol. 33, no. 2, pp. 103-105. DOI: 10.1007/BF02765955.

38. Merzhanov A.G., Borovinskaya I.P., Prokudina V.K., Pesotskaya N.S., Nasonova M.A. SHS abrasives. Production. Properties. Application. Nauka proizvodstvu, 1998, no. 8 (10), pp. 4-12. (In Russian).

39. Tsuzuki T., McCormick P.G. Synthesis of $\mathrm{Cr}_{2} \mathrm{O}_{3}$ nanoparticles by mechanochemical processing. Acta Mater., 2000, vol. 48, no. 11, pp. 2795-2801. DOI: 10.1016/S1359-6454(00)00100-2.

40. Koroleva (Chekhomova) L.F. Synthesis of Spinel-Based Ceramic Pigments from Hydroxycarbonates. Glass and Ceramics, 2004, vol. 61, nos. 9-10, pp. 299-302. DOI: 10.1023/B:GLAC.0000048695.24873.a9. ISSN 0361-7610.

41. Koroleva L.F. Synthesis and abrasive properties of nanoparticulate $\mathrm{MoO}_{2}$-modified $\mathrm{Al}_{2-\mathrm{x}} \mathrm{Fe}_{\mathrm{x}} \mathrm{O}_{3}$ and $\mathrm{Fe}_{2-\mathrm{y}} \mathrm{Al}_{\mathrm{y}} \mathrm{O}_{3}$ solid solutions. Inorganic Materials, 2010, vol. 46, no. 12, pp. 1330-1336. DOI: 10.1134/S0020168510120113. ISSN 0020-1685.

42. Koroleva L.F. Nanoparticulate zirconia-modified solid solutions of aluminum-iron oxides for polishing titanium metal. Diagnostics, Resource and Mechanics of materials and structure, 2015, iss. 1, pp. 90-102. DOI: 10.17804/2410-9908.2015.1.090-102. Available at: http://dream-journal.org. 
Подана в журнал: 27.01 .2016

УДК 621.82

DOI: $10.17804 / 2410-9908.2016 .2 .048-073$

\title{
МОДИФИЦИРОВАННЫЕ НАНОДИСПЕРСНЫЕ ОКСИДЫ ДЛЯ ФИНИШНОГО ПОЛИРОВАНИЯ МЕТАЛЛОВ
}

\author{
Л. Ф. Королева \\ Федеральное государственное бюджетное учреждение науки Институт машиноведения \\ Уральского отделения Российской академии наук, ул. Комсомольская, 34, Екатеринбург, Российская Федерация \\ *Ответственный автор. Электронная почта: lq@imach.uran.ru; адрес для переписки: ул. Комсомольская, 34, \\ 620049, Екатеринбург, Российская Федерация. Телефон: +7 (343) 374-18-53; факс: +7 (343) 374-53-30
}

Изложена концепция процесса механохимического финишного полирования закаленных сталей и цветных металлов с нанодисперсными абразивными материалами. Установлено, что получаемый из гидроксокомплексов твердый раствор оксидов алюминия и железа на основе корунда и гематита $\mathrm{Al}_{2-\mathrm{x}} \mathrm{Fe}_{\mathrm{x}} \mathrm{O}_{3}$ и $\mathrm{Fe}_{2-\mathrm{y}} \mathrm{Al}_{\mathrm{y}} \mathrm{O}_{3}$, является трибохимически активным, обеспечивает высокую производительность и наношероховатость поверхности $\left(R_{a} 0,005-\right.$ 0,002 мкм) в процессах финишного полирования стали с аустенитно-мартенситной структурой типа марки ШХ-15, а также меди, алюминия и титана и их сплавов. Модифицирование твердого раствора оксидов алюминия и железа оксидами молибдена, марганца и циркония обеспечивают наношероховатость поверхности в процессах финишного полирования цветных металлов.

Ключевые слова: модифищирование, твердые растворы, оксиды, финишное полирование, механохимия.

\section{1. Введение}

В прецизионном машиностроении, приборостроительной и электронной промышленности требуется качественная обработка поверхности металлов с получением шероховатости менее 0,005 мкм, что гарантирует необходимые эксплуатационные характеристики, надежность приборов. Отечественное производство не удовлетворяет потребность в абразивных порошковых материалах для доводочных операций полирования высокоточных металлоизделий. Проблемной является задача получения шариков подшипников с шероховатостью поверхности $R_{z}$ менее чем 0,06 мкм $R_{a}$ менее 0,005 мкм) и степени точности 10 (для размеров шариков $1 / 16$ и $3 / 16$ дюйма), используемых в системах ракет.

В электронике полирование с получением наношероховатой поверхности существенно определяет последующие процессы эпитаксии и нанесения различных слоев: диэлектрических, отражающих, пропускающих, проводящих. В оптоэлектронике переход от субмикронных к нанометрическим размерам топологических элементов новых приборов с применением поверхностных слоев толщиной 5-15 нм и минимальным геометрическим рельефом.

Финишное полирование металлов - получение шероховатости поверхности $R_{a} 0,005-$ 0,002 мкм, т.е. процесс обработки материалов до получения зеркальной поверхности, когда глубина неровностей меньше 1/200 волны видимого света или менее 2 нм. Этот процесс можно осуществить следующими методами: механическим полированием, химикомеханическим (электрохимическим) полированием, ионно-лучевым (для неметаллов) и механохимическим полированием, т. е. механическим действием с использованием трибохимически активных абразивных материалов, приводящих к химическим процессам.

Для получения минимально шероховатой поверхности механическим полированием применяют абразивные дисперсные материалы с высокой твердостью, например, наноалмаз- 
ные порошки, как природные, так и синтетические, а также карбиды бора и кремния, кубический нитрид бора с зернистостью от 0,01 - 0,3 мкм до 6-10 мкм, находят применение и ультрамикропорошки на основе корунда. При использовании этих материалов отмечается длительность и многостадийность процесса. Обычно доводочное полирование прецизионных изделий осуществляется за 2 - 5 операций с последовательным уменьшением зернистости абразива в составе паст и суспензий, используемых на операциях предварительной, чистовой и тонкой доводки [1-8].

К производительным абразивным материалам для прецизионных доводочных операций металлов относят абразивы со средней твердостью на основе оксидов. К ним следует отнести оксиды переходных и редкоземельных металлов со средней твердостью (по шкале Mооса, 5 - 7 баллов), в число которых входят: $\mathrm{CeO}_{2}, \mathrm{ZrO}_{2}, \mathrm{Cr}_{2} \mathrm{O}_{3}, \mathrm{Al}_{2} \mathrm{O}_{3}, \mathrm{Fe}_{2} \mathrm{O}_{3}$ [9, 10]. Однако они не всегда обеспечивают получение высокого класса чистоты обработки поверхности, например, оксид хрома как наиболее применяемый из мягких абразивных материалов. Возможный способ улучшения абразивных свойств является модифицирование с образованием твердых растворов оксидов [11].

Твердые растворы на основе оксидов алюминия обеспечивают высокую производительность и получение высокого класса чистоты обработки поверхности. Экологически чистым является абразивный материал на основе твердых растворов оксидов алюминия и железа [12].

Известно, что качество полирования определяется структурным состоянием и технологией подготовки поверхности обрабатываемого тела, условиями на границе твердых тел: величиной поверхностной энергии, адгезией и адсорбцией абразивного материала, процессами смачивания поверхности металла.

Механическое полирование является комплексным взаимодействием обрабатываемого материала, полировальника и абразивных частиц [13]. Процессы, происходящие при полировании следующие: адсорбция, смачивание, адгезия, образование новых фаз и поверхностей, пластическая деформация.

С точки зрения механики твердого тела механическое полирование можно отнести к процессам трения пары скольжения. Сам процесс деформации при трении, как показано в [14], происходит в три стадии: на первой происходит упругопластическая деформация; на второй - пластически-деструкционная; на третьей - появление и распространение магистральных трещин, ведущих к разрушению материала. Отмечается периодичность структурных изменений в процессе многоцикловой нагруженности.

Определяющие факторы в механическом полировании следующие: 1) средний размер основной фракции абразива; 2) концентрация абразива в жидкой фазе; 3) кристаллическая форма и микротвердость абразива и полируемого металла; 4) удельное давление, оказываемое на поверхность; 5) площадь контакта обрабатываемой поверхности и рабочей поверхности полировальника; 6) скорость полирования.

В соответствии с [15] съем металла $C_{M}$ и шероховатость обрабатываемой поверхности $R_{z}$ зависят от среднего размера основной фракции абразива и определяются по уравнениям:

$$
\begin{gathered}
C_{M}=\frac{c_{q} v p^{r} d^{u} w^{f}}{s^{m}} ; \\
R_{z}=c_{n} \sqrt{d},
\end{gathered}
$$

где $c_{q}$ и $c_{n}-$ коэффициенты, зависящие от свойств материала, абразива и условий обработки; $v$ - скорость полирования; $p$ - давление на обрабатываемую поверхность; $d$ - средний размер основной фракции абразивного материала; $w$ - концентрация абразивного порошка в жидкой 
фазе по массе; $s$ - площадь контакта обрабатываемой и рабочей поверхностей инструмента; $r=0,7-1,0$.

При использовании ультрадисперсных наноалмазов, корундов, нитридов бора, т.е. абразивов с высокой твердостью, полирование является механическим процессом микрорезания неровностей и сглаживания рельефа. Удельный вес работы трения в процессах шлифования довольно велик, и 80 \% механической работы при шлифовании переходит в теплоту, а остальная часть превращается в потенциальную энергию деформации кристаллической решетки. За счет температурного фактора в поверхностном слое обычно возникают растягивающие остаточные напряжения. В результате обработки металлов при больших скоростях в поверхностном слое происходят структурные изменения, которые приводят к вторичной закалке и образованию подповерхностного слоя повышенной твердости по сравнению с основной структурой. Например, при шлифовании стали ШХ-15 и других высоколегированных закаленных сталей в результате вторичной закалки образуется подповерхностный слой с аустенитно-мартенситной структурой, имеющий повышенную твердость и хрупкость. Ниже этого слоя лежит переходная зона со структурой, состоящей из феррита, остаточного аустенита и цементита [16].

Применение нанодисперсных трибохимически активных абразивных материалов существенно изменяет процесс, так как происходят химические реакции, что позволяет сократить количество доводочных операций, т.е. предварительную, чистовую и тонкую доводочную обработку свести к одной с получением наношероховатой поверхности.

Модель химико-механического полирования и концепция молекулярного воздействия абразивных частиц суспензии на поверхность полируемой поверхности с учетом окисляющей способности компонентов и образования тонких оксидных пленок рассмотрена в [17-19]. В связи с этим развивается теория молекулярно-атомного воздействия абразивного материала на полируемую поверхность [20, 21].

В результате действия трения под нагрузкой в присутствии химически активного абразивного материала и среды идет практически мгновенное окисление поверхностного слоя и образование оксидной пленки, которая легко разрушается и удаляется с поверхности. С точки зрения химической природы идет разупорядочение и разрыв химических связей, сопровождающиеся высокой концентрацией активных центров на поверхности металла. К химическим факторам относится трибохимическая активность оксидов. Роль силового воздействия абразивных зерен может быть представлена как механохимическое активирование на контактных точках поверхности металла, приводящее к инициированию химических реакций [22].

Для увеличения производительности процесса полирования цветных металлов и сплавов, вероятно, необходимо повысить окислительную способность абразива или абразивной пасты введением какого-либо окислителя. Другое решение может быть осуществлено за счет модифицирования абразивного материала оксидом переходного металла с переменной степенью окисления. Такой модифицирующей добавкой могут быть оксиды молибдена, марганца, обладающие способностью окислять и образовывать соединения с переменной валентностью.

В настоящей работе с позиций механохимии изложена концепция процесса финишного полирования закаленных сталей с аустенитно-мартенситной структурой и цветных металлов нанодисперсными трибохимически активными абразивами. Расмотрены основы синтеза нанодисперсных абразивных материалов на основе модифицированных твердых растворов оксидов переходных элементов для финишного полирования и влияния модифицирования на получение наношероховатости поверхности металлов. 


\section{2. Методика эксперимента}

Твердые растворы оксидов алюминия и железа, а также модифицированные оксидами молибдена, марганца и циркония, получали термообработкой аммиачных гидроксокарбонатов, полученных осаждением в интервале температур $1000-1150{ }^{\circ} \mathrm{C}$. В процессе осаждения вводили молибдат-ионы в виде $0,1 \mathrm{M}$ раствора $\left(\mathrm{NH}_{4}\right)_{6} \mathrm{Mo}_{7} \mathrm{O}_{24}$, ионы марганца - в виде $0,1 \mathrm{M}$ раствора $\mathrm{MnSO}_{4}$, цирконил-ионы в виде $0,1 \mathrm{M}$ раствора $\mathrm{ZrOSO}_{4}$. Концентрацию оксида железа в готовом продукте варьировали в интервале $0,12-0,2$ мол. \%, концентрацию диоксидов циркония, марганца и молибдена - в интервале 0,001 - 0,005 мол. \%. Концентрацию алюминия, железа, и модифицирующих оксидов в образцах осуществляли по стандартным методикам рентгенофлуоресцентного анализа с применением энергодисперсионного спектрометра EDX-900HS с относительной погрешностью $\pm 0,0005$ мол. \%. Концентрацию $\mathrm{NH}_{4}{ }^{+}$определяли фотометрическим методом; концентрацию $\mathrm{CO}_{3}{ }^{2-}-$ волюмометрическим методом с улавливанием углекислого газа раствором щелочи после нагревания при $220-250{ }^{\circ} \mathrm{C}$ образцов, высушенных при комнатной температуре; концентрацию суммы $\mathrm{OH}^{-}$и $\mathrm{CO}_{3}{ }^{2-}$ групп - оксалатным.

Для исследования образцов применяли следующие методы: ИК-спектроскопический с использованием спектрофотометра JR-475 фирмы Shimadzu (образцы прессовали в таблетки с КBr); рентгенофазовый анализ (РФА) с использованием дифрактометра STADI-P с программой, включающей сопоставление дифракционных максимумов с данными картотеки JCPDS-JCDD PDF2, в $K_{\alpha}$ излучении медного анода. Для фильтрации $\beta$ излучения использовали никелевый фильтр. Шаг сканирования составил $0,03^{\circ}$ в области спектра $2 \Theta$ от 5 до $70^{\circ}$, подсчет секунд от 5 до 25 для каждого шага. Гранулометрический состав образцов устанавливали методом седиментации с помощью центрифугального седиментографа фирмы Shimadzu “Analyzier SA-CP2” (вязкость дисперсионной среды 0,0093 пуаз; плотность жидкой

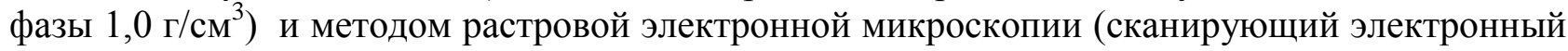
микроскоп TECKAH Вега II XMU Uacc = 15 кв). Термические и термогравиметрические эффекты были исследованы с помощью ДТ-анализа (дериватограф Q-1500D фирмы Paulik, Paulik, Erdei) в процессе нагрева образцов при скорости нагрева $10-11{ }^{\circ} \mathrm{C} / \mathrm{Mин,} \mathrm{в} \mathrm{интервале}$ 20-1000 ${ }^{\circ} \mathrm{C}$, с навеской 500 мг.

Абразивные свойства образцов в процессах полирования исследовали согласно стандартным методикам определения полирующей способности и шероховатости поверхности с помощью оптического профилометра Wyko NT-1100 $\left(R_{a}\right)$ и атомносиловой микроскопии $(\mathrm{ACM})$ с применением сканирующего зондового микроскопа “НаноСкан”, работающего в жестком контактном режиме (рис. 1).

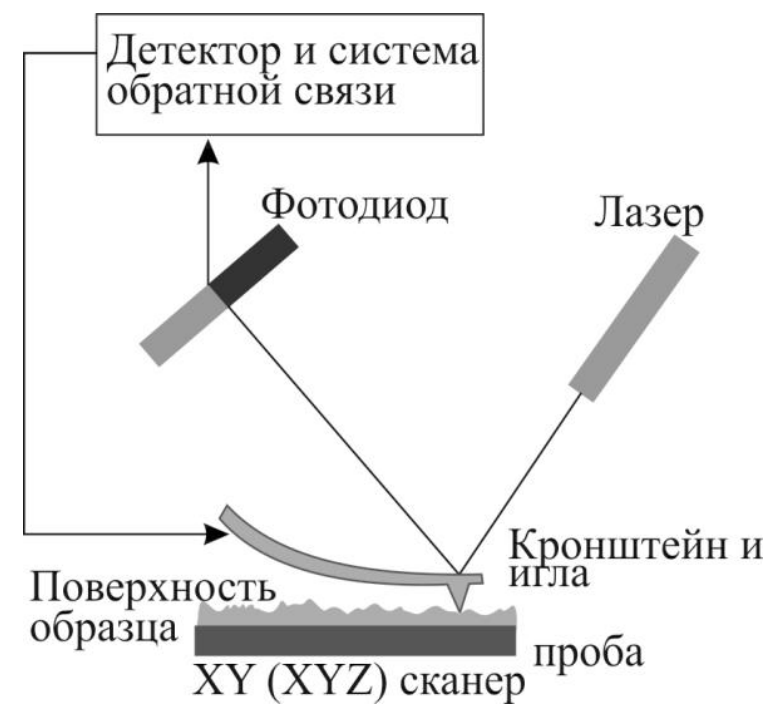

Рис. 1. Схема атомно-силового микроскопа 
Рельеф поверхности регистрируется в виде дискретной функции $\mathrm{Z}=\mathrm{f}(\mathrm{x}, \mathrm{y})$, определенной на двумерном массиве дискретных переменных. При измерении шероховатости поверхности максимальное поле сканирования составляло $9 \times 9$ мкм с разрешением $512 \times 512$ точек при скорости сканирования 30 мкм/с. Исследование шероховатости представляет собой серию снимков различных участков поверхности. В каждом кадре рассчитаны параметры стандартного отклонения высот. В результате шероховатость поверхности оценивалась в среднем по набору кадров одинакового размера. Шероховатость поверхности $R_{a}$ представляет среднее арифметическое абсолютное значение отклонений в пределах длины профиля и определяется следующим образом:

$$
R_{a}=1 / \mathrm{n} \sum\left|\mathrm{y}_{\mathrm{i}}\right|
$$

где n - число выбранных точек профиля на базовой длине.

Значение стандартного отклонения высот рельефа поверхности может быть вычислено по формуле:

$$
\sigma=\sqrt{1 / N^{2}\left[\sum_{i, j} Z_{i, j}-\bar{Z}\right]^{2}} .
$$

Исходные образцы для полирования - сталь ШХ-15, сплав алюминия Д-16 (92 \% Al), медь М-1 (Си 99,8 \%), латунь марки Л-63 (Cu 63 \%), титан ВТ1-00 (99,9 \% Ті) - имели начальное значение шероховатости поверхности $R_{a}=1,3 \div 1,6$ мкм. Образцы цилиндрической формы: диаметр 17 мм, высота 20 мм. В эксперименте каждая точка определялась по пяти образцам. Полученные результаты обработаны с помощью методов математической статистики и выборки проверены на нормальное распределение. Производительность процесса полирования (полирующую способность) вычисляем по формуле

$$
\mathrm{P}=\frac{\Delta \mathrm{M}}{\mathrm{S} \cdot \mathrm{t}}
$$

где $\Delta \mathrm{M}$ - среднее изменение массы образцов в процессе полирования, мг; $\mathrm{S}$ - площадь полируемой поверхности образцов, см$^{2} ; \mathrm{t}$ - длительность полирования, мин.

Для моделирования процесса полирования была смонтирована специализированная установка на базе вибрационного прибора «Метаполан 2» (рис. 2). Образцы были помещены в специальные держатели на платформе (1), покрытой тканью - сукном (2), куда вносилась полировальная паста. Контактное давление 12 - 18 кПа (9), вращение образцов осуществлялось за счет вращения шпинделя (7) от электродвигателя (4), скорость вращения 89 об/мин $(1,4$ м/с) регулировалась резистором (5). Каждые 15 мин наносили полировальную пасту, состоящую из воды и абразивного порошка. Для полирования была подготовлена паста из абразивного порошка (10 г) и дистиллированной воды (90 мл) со значением рН среды 7-8. Агломерации пасты не наблюдалось в течение всего процесса полировки. Контроль над процессом осуществляли по изменению съема металла и качества поверхности по шероховатости. 

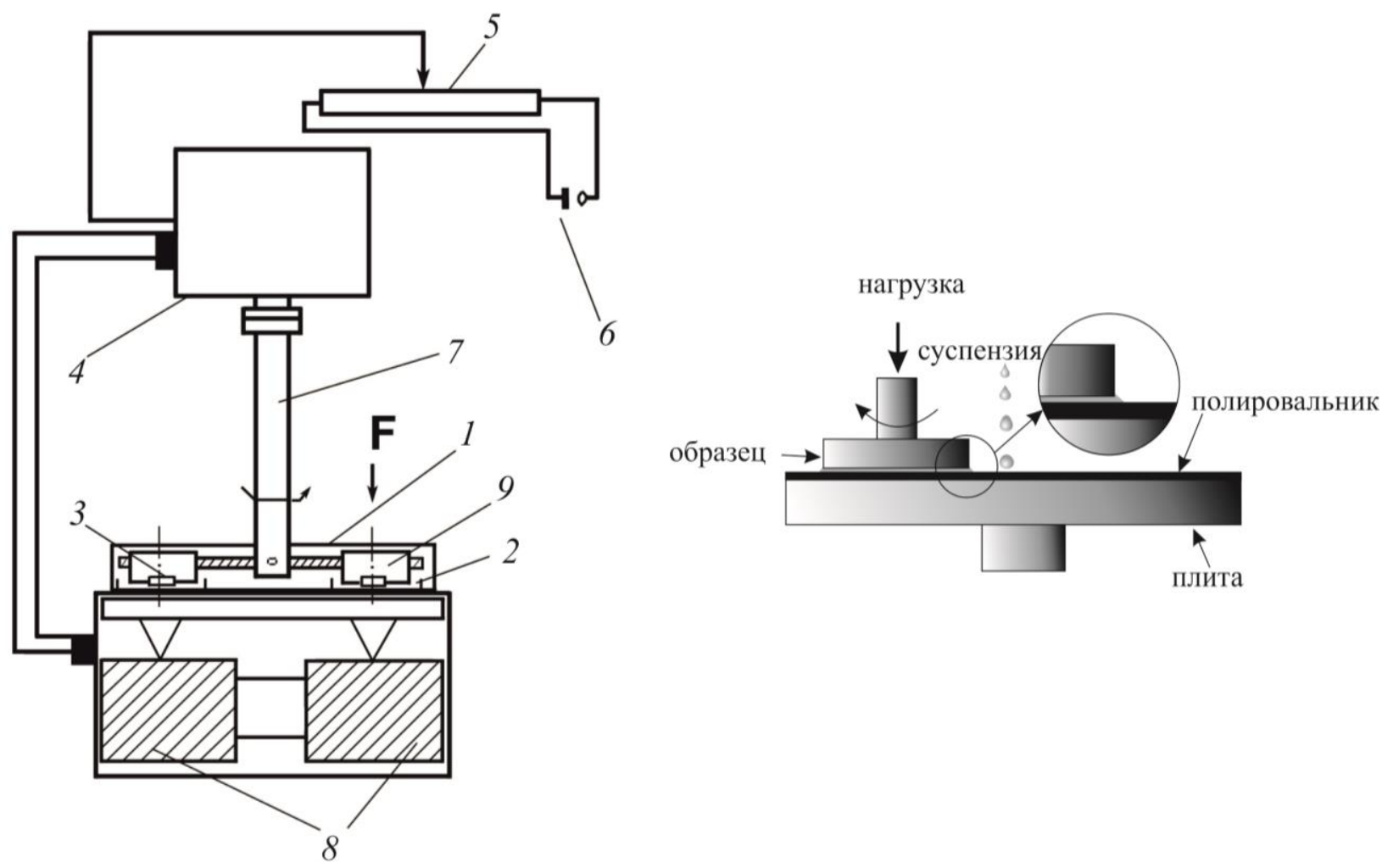

Рис. 2. Схема установки полирования: 1 - плита; 2 - лоток для полировальной пасты; 3 - образец; 4 - электродвигатель; 5 - резистор; 6 - источник энергии; 7 - шпиндель; 8 - электромагниты; 9 - нагрузка

\section{3. Результаты и обсуждение}

Механохимическое полирование является многоцикловым процессом, происходящим в результате трения под давлением на поверхность полируемого тела в присутствии полировальной пасты с трибохимически активными абразивными частицами. Данные процессы относят к физико-химической механике.

По определению Ребиндера [23, 24], полирование поверхностей металла относится к процессам обработки давлением, когда под воздействием внешних сил в слоях, прилегающих к поверхности, возникает течение металла, приводящее к поверхности предельной гладкости. Введение поверхностно-активных веществ, являющихся адсорбционными пластификаторами металла, способствует снижению шероховатости трущихся поверхностей, ускоряет сам процесс и повышает качество полирования, облегчая пластическое затекание металла. Зарождение и развитие различных форм локальной неоднородности кристаллических материалов, приводящей в итоге к разрушению, определяется особенностями поведения поверхностных слоев в процессе пластического деформирования. Начальные акты пластического течения, как правило, связаны с поверхностными слоями.

Химическая активность абразивных частиц будет определять химические превращения в подповерхностном слое металла. Применение химически активных абразивов дает возможность в результате полирования перейти от грубой поверхности к зеркальной за одну доводочную операцию. Следовательно, данный процесс обусловлен в большей степени немеханическим воздействием. Роль силового воздействия абразивных зерен может быть представлена как механохимическое активирование контактных точек поверхности металла, приводящее к инициированию химических реакций, без которых получить минимальную шероховатость поверхности не удается. Под воздействием трения в присутствии химически активного абразивного материала и среды идет практически мгновенное окисление поверх- 
ностного слоя и образование оксидной пленки, которая легко разрушается и удаляется с поверхности.

Полирование характеризуется процессами абразивного разрушения поверхностных слоев и образованием новых твердых фаз на границе раздела. Под действием зерен абразива происходит упругопластическая деформация металла, вызывающая изменение физикохимических свойств тонкого подповерхностного слоя, в том числе термодинамического и химического потенциалов.

В общем случае химический потенциал $\mu$ определяется как изменение энергии Гиббса $G$ :

$$
\mu=(F-T S+P V) / N=G / N .
$$

Свободная энергия $d F$ системы в процессе полирования при постоянном объеме зависит от изменения энтропии $d S$, химического потенциала компонентов материала $\mu_{i}$ и свободной поверхностной энергии $\gamma$ вновь образующейся поверхности. Ее можно представить следующим уравнением для квазистатических систем [25]:

$$
d F=-T d S+\sum \mu_{i} d N_{i}-\gamma d A,
$$

где $N_{i}$ - число частиц $i$-го компонента; $\gamma$ - поверхностное натяжение или поверхностная свободная энергия; $A$ - площадь образующейся поверхности.

Главная причина возрастания химической реакционной способности поверхности металла состоит в увеличении энтальпии из-за изменения его реальной структуры. Энергия упругих искажений решетки, возникающих вследствие пластической деформации тела, эквивалентна увеличению энтальпии тела, а в случае образования дислокаций, когда можно пренебречь энтропийной составляющей, она эквивалентна увеличению термодинамического потенциала.

Под воздействием трения в присутствии химически активного абразивного материала и среды идет практически мгновенное окисление поверхностного слоя и образование оксидной пленки, которая легко разрушается и удаляется с поверхности.

Как известно, пленки на металлах по толщине принято подразделять на три группы: тонкие (невидимые), толщина которых от нескольких ангстрем до 40 нм; средние (дающие цвета побежалости), толщина которых 40-500 нм и толстые видимые, толщина которых более 500 нм. Рост оксидных пленок может быть выражен степенным законом при диффузионно-кинетическом режиме [26]:

$$
h^{n}=k^{n} \tau
$$

где $h$ - толщина пленки; $\tau$ - продолжительность образования пленки; $k, n-$ коэффициенты.

При диффузионном контроле роста пленок действует параболический закон [26]:

$$
h^{2}=k \tau+C,
$$

где $k, C$ - постоянные.

При диффузионно-кинетическом контроле скорость химической реакции и скорость диффузии равны. Например окисление углеродистой стали $(0,6 \% \mathrm{C})$ при $800{ }^{\circ} \mathrm{C}$ на воздухе, насыщенном парами воды.

Величина поверхностной энергии вновь образующейся поверхности (в основном это все-таки оксидные пленки различной толщины) определяет прочностные характеристики материала. Правомерно для изотропных поверхностей представить напряжение, возникающее 
в процессе образования оксидной пленки на ювенильной поверхности металла $\sigma_{s}$, уравнением [25]:

$$
\sigma_{s}=\gamma+\Delta \frac{d \gamma}{d A}
$$

где $\gamma$ - поверхностное натяжение или поверхностная свободная энергия; $A$ - площадь образующейся поверхности; $\Delta$ - изменение площади поверхности.

Согласно теории роста тонких оксидных пленок Кабреры и Мотта [27, 28], контролирующей стадией окисления является перенос ионов металла под влиянием ускоряющего электрического поля внутри пленки, образованных на границе раздела металл-пленка положительными ионами металлов и отрицательными ионами хемосорбированного кислорода.

В результате полирования нанодисперсными твердыми растворами оксидов алюминия и железа, установлено, что в процессе полирования образцов закаленной стали ШХ-15 на начальной стадии (в течение 15 мин) происходит увеличение массы образцов за счет внедрения кислорода и окисления подповерхностного слоя, что подтверждается наблюдаемым увеличением массы образцов. С учетом удельной плотности материала и полируемой площади это соответствует толщине окисленного подповерхностного слоя, равного 1500-4000 нм, т.е. наблюдается образование толстых пленок. Если абразивный материал содержит нанодисперсные фракции, то возникшая пленка легко снимается через механическое воздействие частиц абразивного порошка, практически не повреждая поверхности. На следующем этапе полирования продолжительностью 30-60 мин образуется гладкая поверхность с получением средних и тонких оксидных пленок на поверхности, экранирующих ее. На рис. 3 представлены различной толщины оксидные пленки, образующиеся в процессе полирования стали ШХ-15: $a$ - в начале процесса; $\sigma$ - в конце процесса; 6 - образование толстых пленок при использовании абразивного материала модифицированного марганцем твердого раствора оксидов алюминия и железа.

По данным электронной микроскопии наблюдается внедрение в небольшом количестве оксида алюминия в подповерхностный слой стали: содержание оксида алюминия составляет до 0,1\% $\mathrm{Al}_{2} \mathrm{O}_{3}$. Также было выявлено, что при полировании стали ШХ-15 происходит незначительное снижение микротвердости от 1030 до 925 - 930 кГ/мм² при использовании в качестве абразивного материала модифицированного оксида хрома или сложных оксидов алюминия и железа, что свидетельствует о незначительном изменении упрочнения в подповерхностном слое и механохимическом процессе полирования (рис.4).

При полировании могут возникнуть напряжения в пленках, например: 1) внутренние напряжения сжатия на неровной поверхности металла образуют отрывающие усилия; 2) внутренние сжимающие напряжения, появляющиеся при росте пленки.

Таким образом, финишное полирование с трибохимически активными абразивами представляет собой процесс, в котором механическое воздействие инициирует химические превращения, ведущие к сглаживанию поверхности, поэтому его можно отнести к механохимическим. 

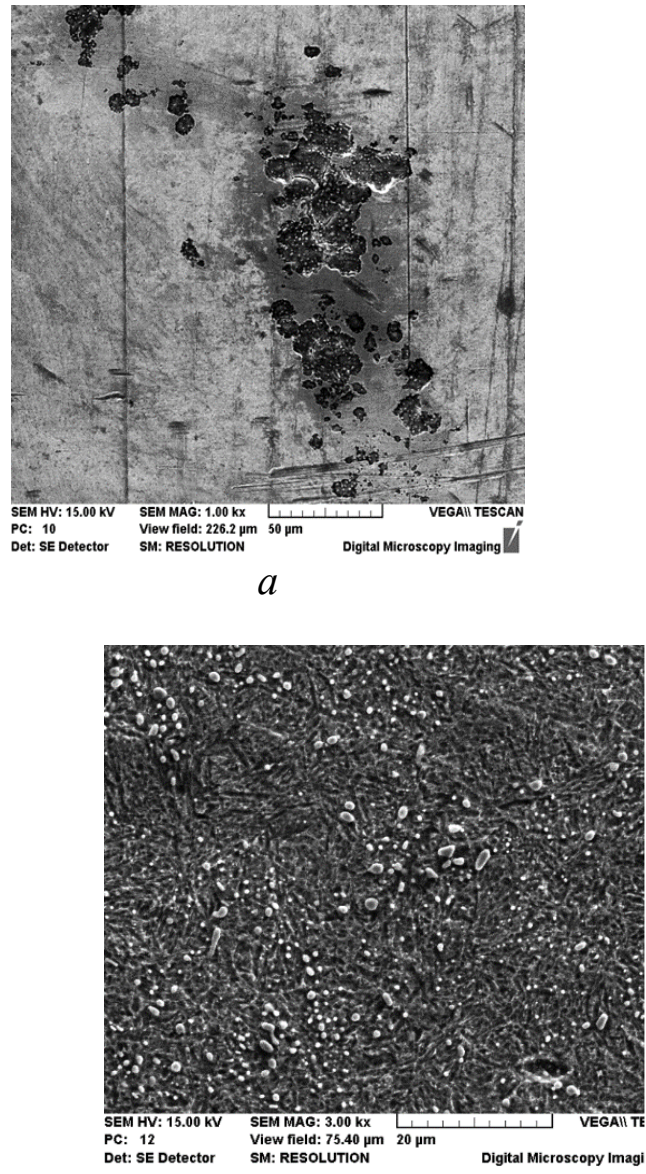

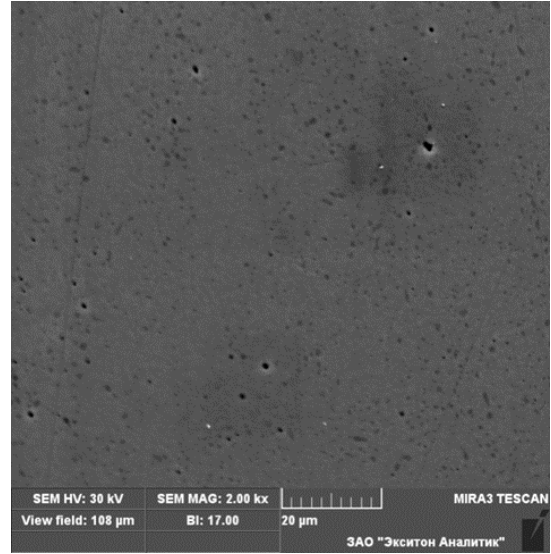

$\sigma$

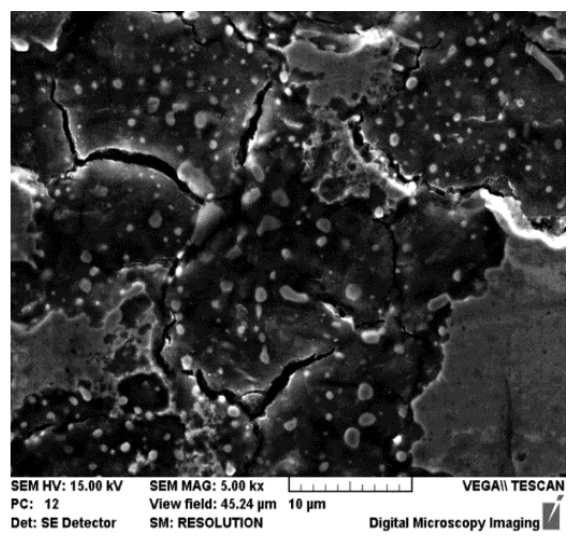

B

Рис. 3. Оксидные пленки, образующиеся в процессе полирования стали ШХ-15: $a$ - в начале процесса; $\sigma$ - в конце процесса; 8 - образование толстых пленок при использовании абразивного материала модифицированного марганцем твердого раствора оксидов алюминия и железа

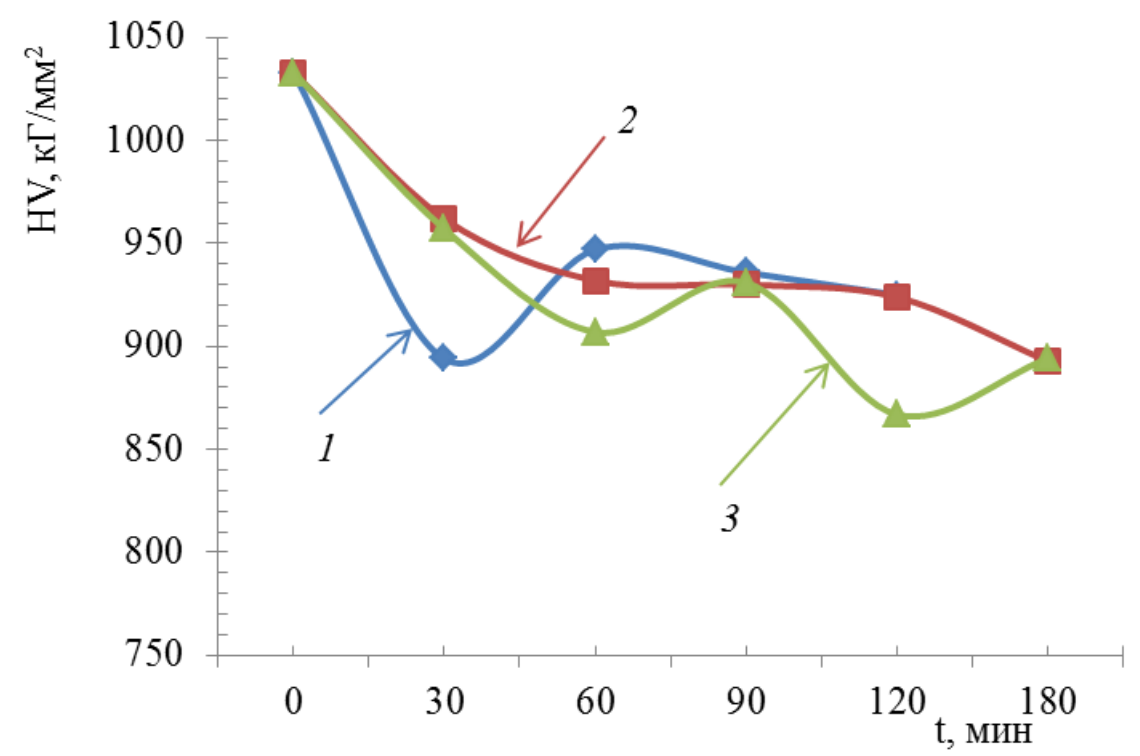

Рис. 4. Зависимость микротвердости стали ШХ-15 от продолжительности полирования: 1 - с модифицированным оксидом хрома [11]; 2 - с твердым раствором оксидов алюминия и железа; 3 - с твердым раствором оксидов алюминия и железа в условиях вибрационного режима [29] 
Изменение электронной подсистемы для стали: окисление $\mathrm{Fe}^{\mathrm{o}} \rightarrow \mathrm{Fe}^{2+} \rightarrow \mathrm{Fe}^{3+}$. Электронно-спиновые изменения в частично заполненных оболочках:

$$
3 d^{6} 4 s^{2} \rightarrow 3 d^{6} 4 s^{o} \rightarrow 3 d^{5} 4 s^{o} .
$$

Изменение электронной подсистемы для титана, происходит следующее: $\mathrm{Ti}^{\circ} \rightarrow \mathrm{Ti}^{2+} \rightarrow \mathrm{Ti}^{4+}$. Электронно-спиновые изменения в подуровне могут быть представлены следующим образом: $3 \mathrm{~d}^{2} 4 \mathrm{~s}^{2} \rightarrow 3 \mathrm{~d}^{2} 4 \mathrm{~s}^{\mathrm{o}} \rightarrow 3 \mathrm{~d}^{1} 4 \mathrm{~s}^{\mathrm{o}} \rightarrow 3 \mathrm{~d}^{\mathrm{o}} 4 \mathrm{~s}^{0}$. На начальном этапе полирования в результате действия химических компонентов пасты и механического воздействия абразивных частиц образуются оксиды в подповерхностном слое металла, например следующим образом: $\mathrm{Ti}+\mathrm{O}_{2} \rightarrow \mathrm{TiO} \rightarrow \mathrm{Ti}_{3} \mathrm{O}_{5} \rightarrow \mathrm{Ti}_{2} \mathrm{O}_{3} \rightarrow \mathrm{TiO}_{2}$

Процесс полирования является многофакторным, и его математическое описание осложнено тем, что он не является только процессом абразивного разрушения поверхностных слоев. Реакционная способность механически обрабатываемой поверхности металла приводит за очень короткую продолжительность к возникновению пленки оксидного слоя, имеющего достаточно сильное адгезионное сцепление с металлической основой. Поверхностное натяжение оксидной пленки определяет прочностные свойства объемного металла.

Учитывая химический состав после полирования подповерхностного слоя металла (табл. 1), высокую производительность, незначительное снижение микротвердости полируемого металла, а также аномальное увеличение массы полируемого образца в начальный период в течение первых 15 мин, что связано с окислением подповерхностного слоя, весь процесс следует отнести к механохимическому. При полировании стали ШХ-15 происходит незначительное снижение микротвердости материала (водная полировальная паста с оксида алюминия-железа) от 1030 до $925 \div 930$ кГ/мм².

Таблица 1 - Элементный состав в мас. \% образцов стали ШХ-15 (числитель) и полированного подповерхностного слоя (знаменатель)

\begin{tabular}{|c|c|c|c|c|c|c|c|}
\hline $\mathrm{C}$ & $\mathrm{Al}$ & $\mathrm{Si}$ & $\mathrm{V}$ & $\mathrm{Cr}$ & $\mathrm{Mn}$ & $\mathrm{Fe}$ & $\mathrm{Ni}$ \\
\hline $1,03 / 1,42$ & $0,0 / 0,08$ & $0,28 / 0,25$ & $0,06 / 0,06$ & $1,64 / 1,52$ & $0,27 / 0,39$ & $96,41 / 96,13$ & $0,18 / 0,15$ \\
\hline
\end{tabular}

В результате под воздействием трения в присутствии химически активного абразивного материала и среды идет практически мгновенное окисление поверхностного слоя и образование оксидной пленки, которая разрушается и удаляется с поверхности.

Так как полирование является процессом на границе твердых тел, включающим окисление и образование оксидной фазы в подповерхностном слое, то всю систему правомерно рассматривать как двухфазную с разделяющей поверхностью, расположенной между объемной и поверхностной фазами металла с обменом ионами и химическим равновесием. Такие процессы относятся к топохимическим, и для описания кинетики полирования с участием реакций в подповерхностном слое можно применить уравнение [30]:

$$
\alpha=1-e^{-k t^{n}},
$$

где $\alpha$ - степень превращения атомов металла в оксиды и определяемая как относительная интенсивность съема металла $\mathrm{C}_{\mathrm{i}} / \mathrm{C}_{\max }$ (принимается априори, что фактор механохимического воздействия абразива является основным); $n$ - число последовательных стадий при образовании центра новой фазы оксидов; $k$ - константа процесса; $t$ - продолжительность процесса полирования. Константу скорости процесса окисления $K_{c \kappa}$ следует определять по уравнению [31]:

$$
K_{c \kappa}=n k^{1 / n}
$$


В табл. 2 даны экспериментальные значения $n, k$ и $K_{c \kappa}$ процесса полирования с примененным удельным давлением 6-12 кПа (дисперсия $S^{2}$ рассчитана по пяти параллельным опытам).

Таблица 2 - Эксперементальные параметры в кинетических уравнениях полирования

\begin{tabular}{|c|c|c|c|c|c|}
\hline \multirow{2}{*}{ Образцы сплавов } & \multirow{2}{*}{$\begin{array}{c}\text { Абразивный } \\
\text { материал }\end{array}$} & \multicolumn{3}{|c|}{$\begin{array}{c}\text { Параметры кинетического } \\
\text { уравнения }\end{array}$} & \multirow{2}{*}{ Дисперсия } \\
\hline & & $n$ & $k$ & $K_{\mathrm{cK}}$ & \\
\hline Сталь ШХ-15 & $\begin{array}{l}\text { Твердый раствор ок- } \\
\text { сидов алюминия и } \\
\text { железа }\end{array}$ & 1,0 & 0,04 & 0,03 & 0,005 \\
\hline Сталь ШХ-15 & $\begin{array}{l}\text { Твердый раствор ок- } \\
\text { сидов алюминия и } \\
\text { железа, модифици- } \\
\text { рованный } \mathrm{MoO}_{2}\end{array}$ & 1,54 & 0,005 & 0,05 & 0,003 \\
\hline Сталь ШХ-15 & Карбид бора $\mathrm{B}_{4} \mathrm{C}$ & 1,3 & 0,01 & 0,004 & 0,005 \\
\hline $\begin{array}{c}\text { Сплав алюминия } \\
\text { Д-16 }\end{array}$ & $\begin{array}{l}\text { Твердый раствор ок- } \\
\text { сидов алюминия и } \\
\text { железа } \\
\end{array}$ & 1,2 & 0,03 & 0,06 & 0,004 \\
\hline $\begin{array}{c}\text { Сплав алюминия } \\
\text { Д-16 }\end{array}$ & $\begin{array}{l}\text { Твердый раствор ок- } \\
\text { сидов алюминия и } \\
\text { железа, модифици- } \\
\text { рованный } \mathrm{MnO}_{2}\end{array}$ & 1,0 & 0,05 & 0,04 & 0,005 \\
\hline Медь М-1 & $\begin{array}{l}\text { Твердый раствор ок- } \\
\text { сидов алюминия и } \\
\text { железа }\end{array}$ & 1,2 & 0,01 & 0,02 & 0,003 \\
\hline Медь М-1 & $\begin{array}{l}\text { Твердый раствор ок- } \\
\text { сидов алюминия и } \\
\text { железа, модифици- } \\
\text { рованный } \mathrm{MoO}_{2}\end{array}$ & 1,2 & 0,03 & 0,05 & 0,005 \\
\hline Титан ВТ1-00 & $\begin{array}{l}\text { Твердый раствор ок- } \\
\text { сидов алюминия и } \\
\text { железа, модифици- } \\
\text { рованный } \mathrm{ZrO}_{2}\end{array}$ & 0,78 & 0,10 & 0,05 & 0,005 \\
\hline
\end{tabular}

На основании проведенного исследования процесса полировании цветных металлов и сплавов было установлено, что модифицирование сложных оксидов алюминия и железа оксидами переходных элементов с переменной валентностью, таких как молибден, марганец $\left(\mathrm{MoO}_{2}, \mathrm{MnO}_{2}\right)$, значительно повышает окислительную способность абразива и увеличивает производительность. Сложные оксиды алюминия и железа, получаемые из гидроксокарбонатных комплексов, обладают высокой полирующей способностью в процессе финишного полирования закаленных сталей и обеспечивает шероховатость поверхности менее $R_{a} 0,005$ мкм, что объясняется повышенной трибохимической активностью абразивных частиц. На рис. 5 приведены кинетические кривые полирования закаленной стали ШХ-15. Для сравнения приведена кривая полирования с карбидом бора, как видно, производительность с ним почти в 2 раза меньше. Наиболее высокая полирующая способность отмечается при по- 
лировании закаленной стали с образцами абразивного материала, содержащих 0,15-0,18 мол. $\% \mathrm{Fe}_{2} \mathrm{O}_{3}$, при мольном соотношении корунда и гематита 4:1 (рис. 6).

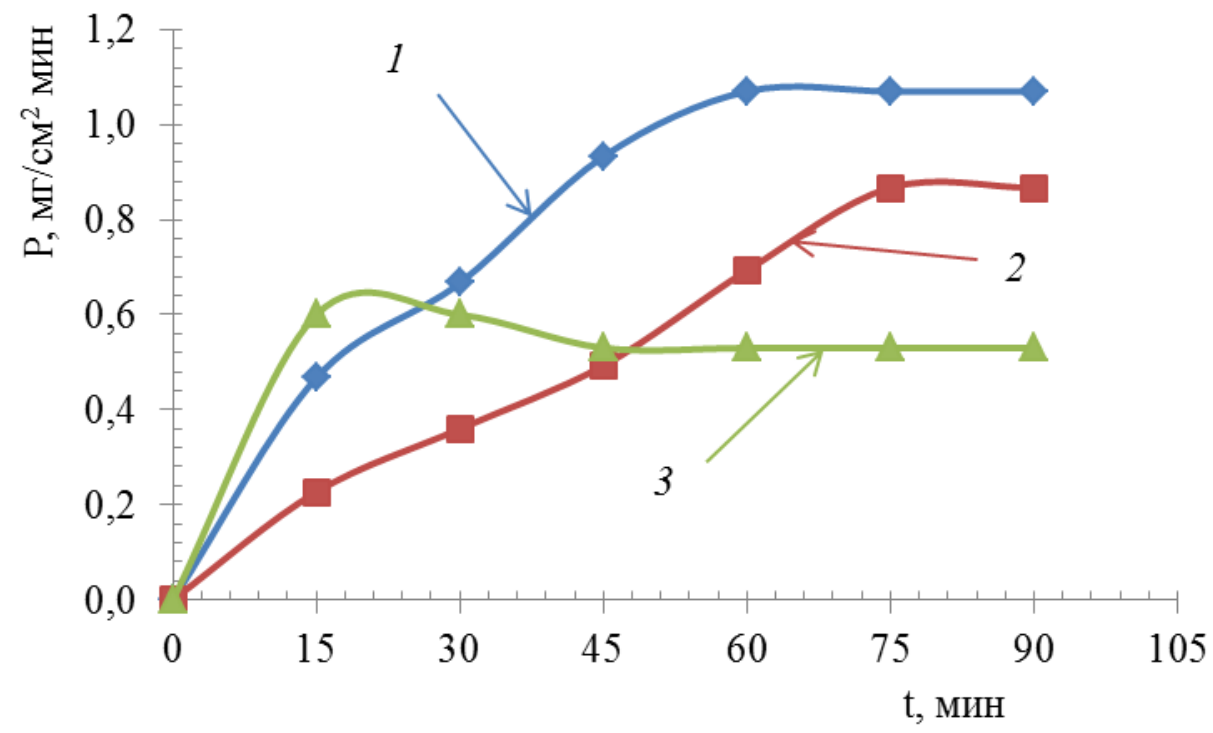

Рис. 5. Кинетические кривые для полирования стали ШХ-15 (Р, мг/см² мин) с твердым раствором $\mathrm{Al}_{2-x} \mathrm{Fe}_{x} \mathrm{O}_{3}: 1$ - 0,175 мол. \% $\mathrm{Fe}_{2} \mathrm{O}_{3} ; 2$ - с 0,014 мол. \% $\mathrm{Fe}_{2} \mathrm{O}_{3} ; 3$ - с карбидом бора

$\mathrm{B}_{4} \mathrm{C}$. Результаты эксперимента были обработаны методами математической статистики

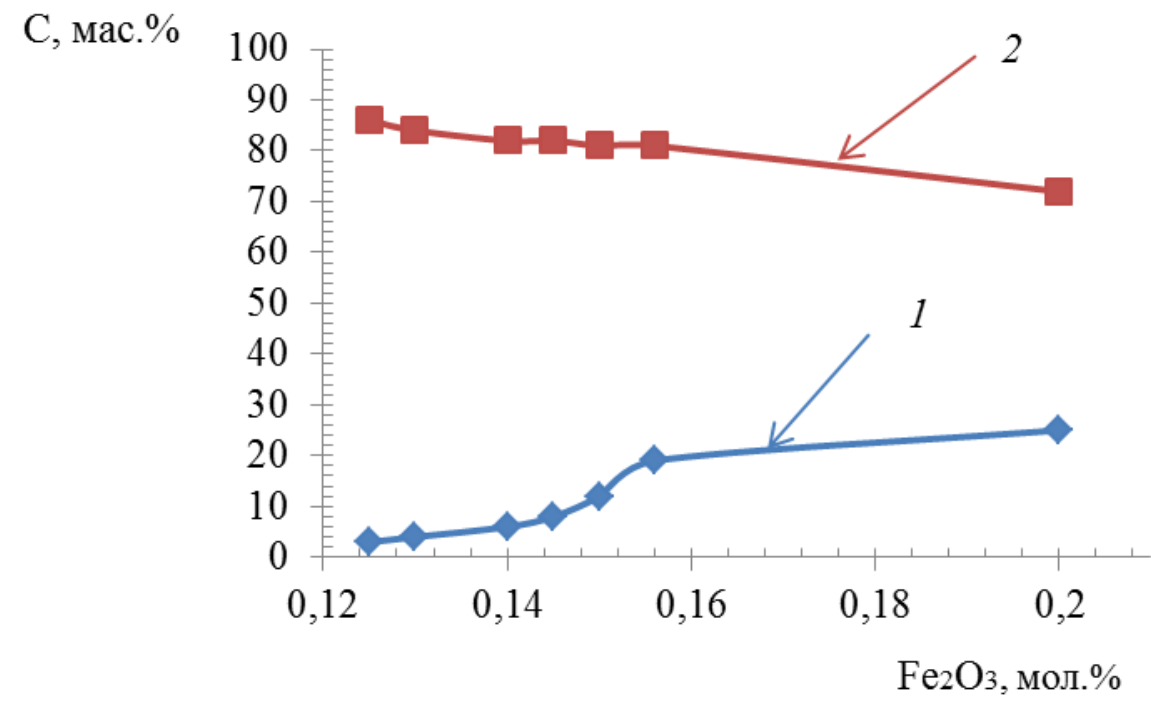

Рис. 6. Зависимость концентрации твердых растворов на основе ромбоэдрического гематита (1) и ромбоэдрического корунда (2) в зависимости от количества введения $\mathrm{Fe}_{2} \mathrm{O}_{3}$

Для полирования цветных металлов и сплавов, таких как медь, латунь, более эффективным является модифицированный оксид алюминия-железа: $0,001-0,005$ мол. $\% \mathrm{MoO}_{2}$, $\mathrm{MnO}_{2}$. На рис. 7 приведены кинетические кривые полирования цветных металлов: меди, латуни и титана. Модифицирование твердого раствора оксидов алюминия и железа диоксидом молибдена $\mathrm{MoO}_{2}$ в количестве 0,001-0,005 мол. \% увеличивает полирующую способность на порядок при полировании меди и латуни, что отражено на кривых.

Для полирования титана наилучшей модифицирующей добавкой к твердому раствору оксидов алюминия и железа является диоксид циркония: модифицирование $\mathrm{ZrO}_{2}$ увеличивает полирующую способность в 3-4,5 раза. Так первоначальная шероховатость поверхности $R_{a}$ 
титана составляла 1,29-1,63 мкм, скорость вращения образов 89 об/мин $(1,4$ м/с), контактное давление 18 кПа, что равно 1/5 от известной для полирования титана корундом [32].

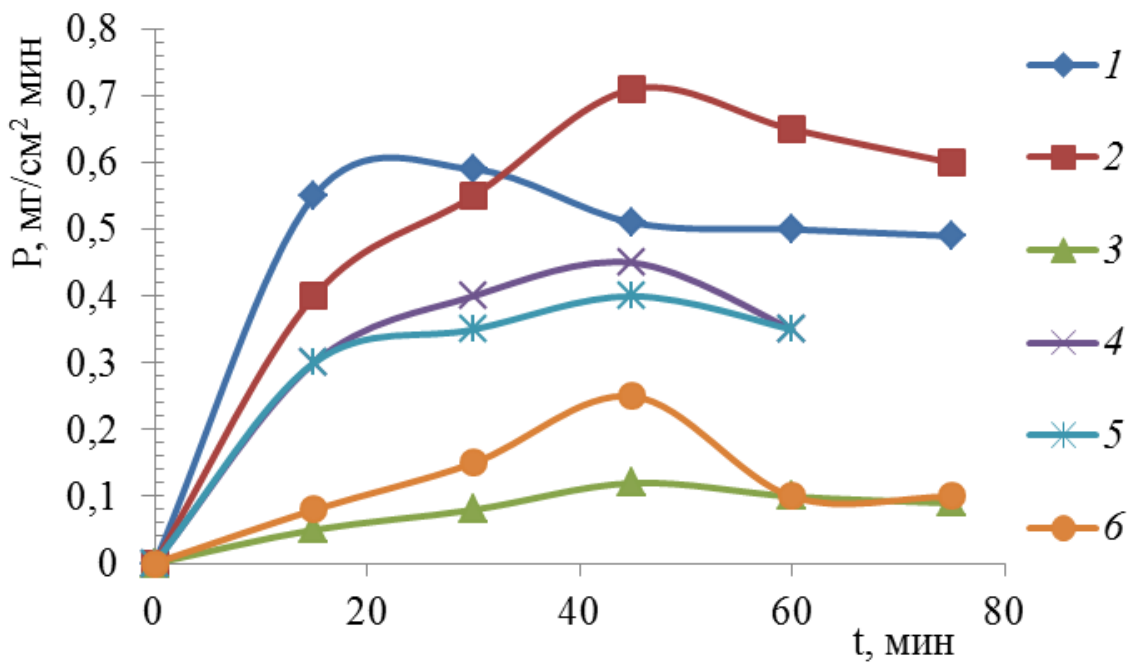

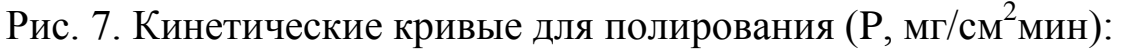

1 - меди с твердым раствором оксидов алюминия и железа, модифицированным $\mathrm{MoO}_{2}$;

2 - латуни с твердым раствором оксидов алюминия и железа, модифицированным $\mathrm{MnO}_{2}$;

3 - меди с немодифицированным твердым раствором оксидов алюминия и железа; 4 и 5 - титана с твердым раствором оксидов алюминия и железа, модифицированным $\mathrm{ZrO}_{2}-$ 0,08 и 0,04 мол. \% соответственно; 6 - алюминия с твердым раствором оксидов алюминия и железа, модифицированным $\mathrm{MnO}_{2}$

Получение наименьшей шероховатости поверхности $R_{a} 0,002$ мкм отмечается с применением твердого раствора оксидов алюминия и железа, содержащих оксид железа в интервале $0,125-0,156$ мол. \%.

На рис. 8 представлены кинетические кривые изменения шероховатости поверхности при полировании образцов закаленной стали и меди с различными абразивами.

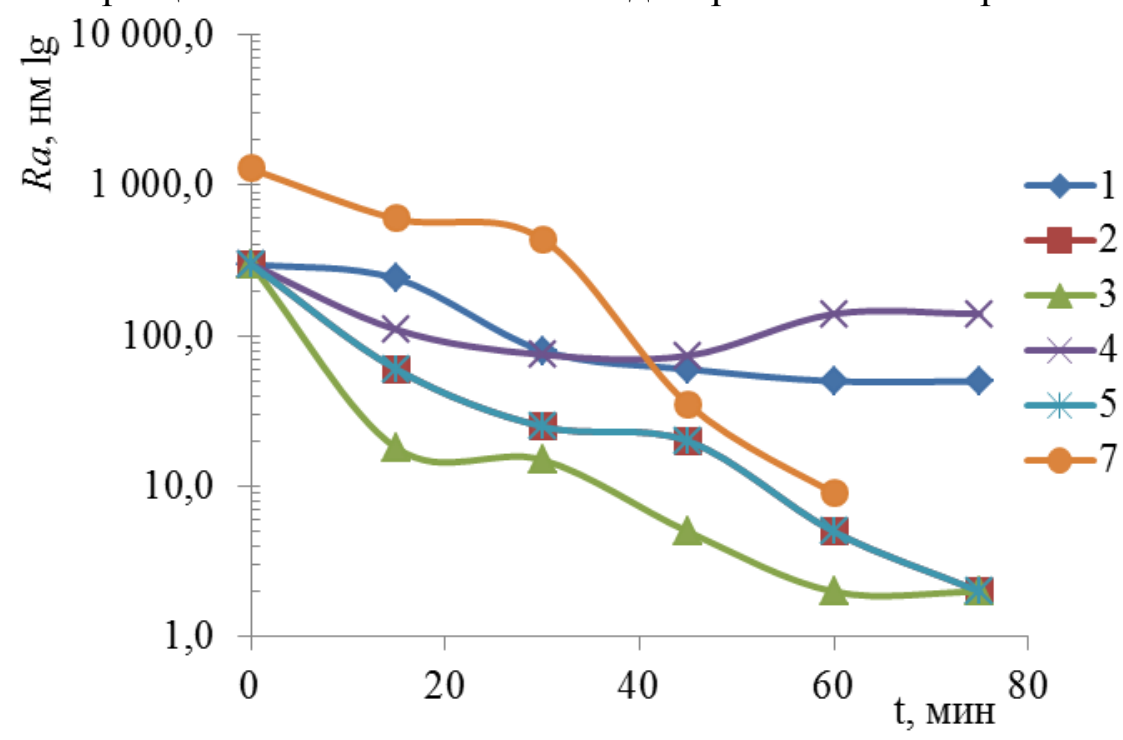

Рис. 8. Кинетические кривые изменения шероховатости поверхности $R_{a}$ при полировании образцов: 1 - меди М-1 твердым раствором оксидов алюминия и железа $\left(0,125\right.$ мол. \% $\left.\mathrm{Fe}_{2} \mathrm{O}_{3}\right)$;

2 - меди М-1 твердым раствором оксидов алюминия и железа, модифицированным $\mathrm{MoO}_{2}$;

3 - стали ШХ-15 твердым раствором оксидов алюминия и железа $\left(0,125\right.$ мол. \% $\left.\mathrm{Fe}_{2} \mathrm{O}_{3}\right)$;

4 - стали ШХ-15 карбидом бора; 5 - меди М-1 твердым раствором оксидов алюминия и железа, модифицированным $\mathrm{MnO}_{2}$ 
Результаты определения шероховатости методом атомносиловой микроскопии приведены на рис. 9. Наименьшей шероховатостью обладают образцы стали, полированные твердым раствором оксидов алюминия и железа, а также образцы меди, полированные с модифицированным $\left(\mathrm{MoO}_{2}, \mathrm{MnO}_{2}\right)$ твердым раствором оксидов алюминия и железа.

Для сравнения приведены результаты полирования с использованием карбида бора $\mathrm{B}_{4} \mathrm{C}$ той же дисперсности: минимально достигаемая шероховатость поверхности равна $R_{a}$ 0,075 мкм. Это подтверждает вывод о том, что финишное полирование является эффективнее с трибохимически активными абразивными материалами.
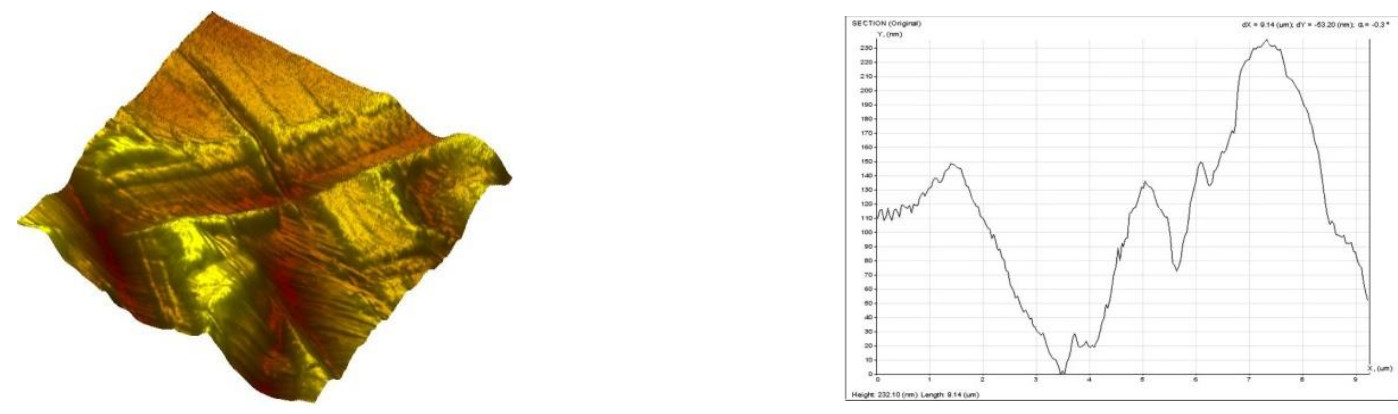

$a$
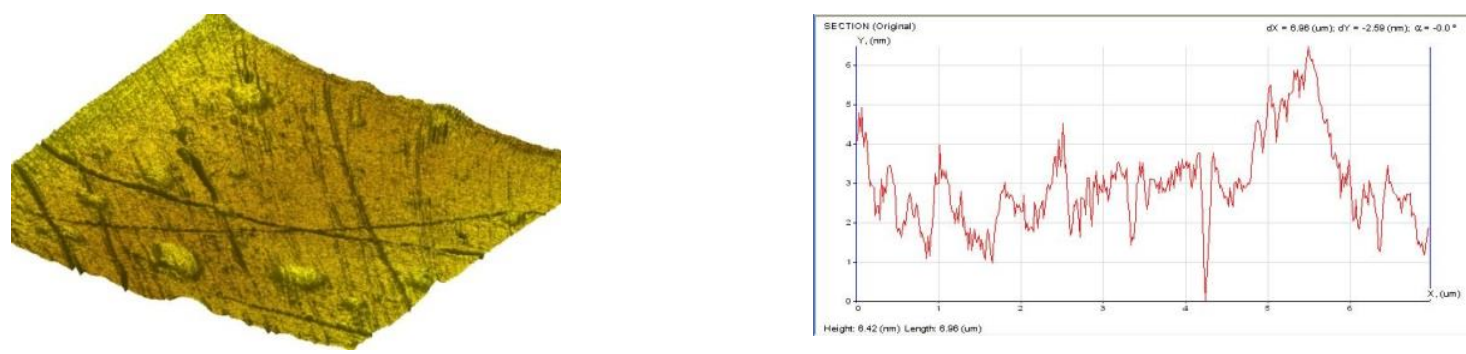

$\sigma$
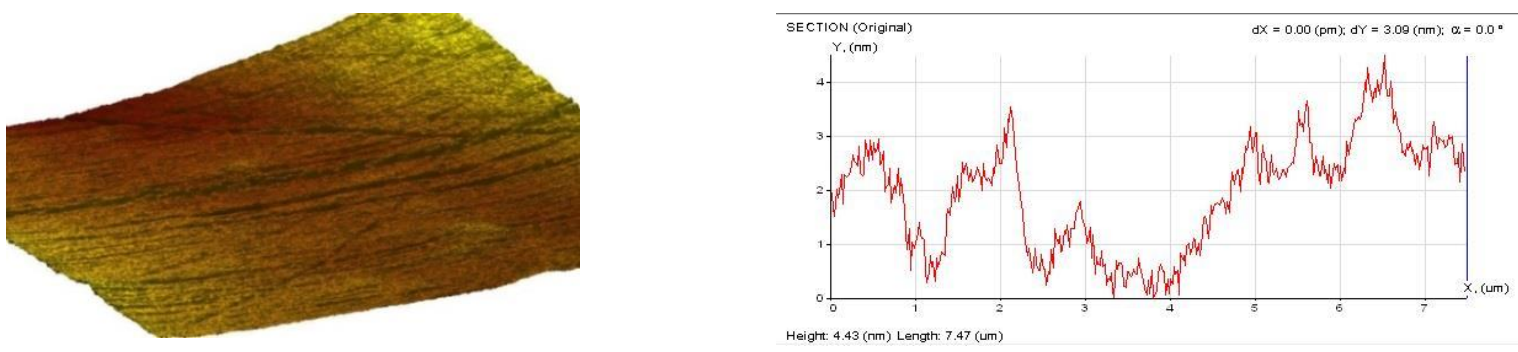

B

Рис. 9. Характерное АСМ изображение рельефа поверхности стали ШХ-15:

$a$ - исходный образец $R_{a} 0,1$ мкм; $\sigma$ - образец, полученный в результате полирования в течение 0,5 ч; 8 - полученный в результате полирования в течение $1-1,5$ ч твердым раствором оксидов алюминия и железа

В результате исследования процессов полирования титана сложными оксидами алюминия и железа (твердым раствором оксидов алюминия и железа), модифицированными диоксидом циркония, были установлены следующие закономерности. Так, сложные оксиды алюминия и железа, модифицированные диоксидом циркония, получаемые из гидроксокарбонатных комплексов, обладают повышенной полирующей способностью в процессе финишного полирования титана и его сплавов. Обеспечивают шероховатость поверхности $R_{a}$ 0,009-0,019 мкм, что объясняется как повышенной трибохимической активностью абразивных частиц, так и увеличением твердости абразивного материала. 
На рис. 10. приведены электронно-микроскопические снимки поверхности стали ШХ-15 после полирования.

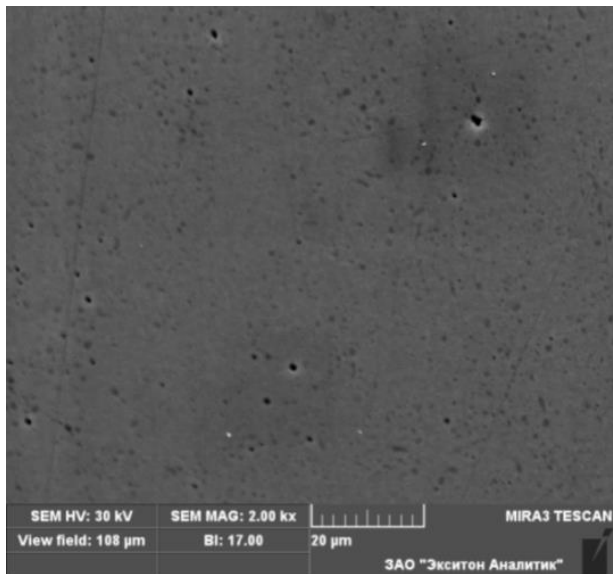

$a$

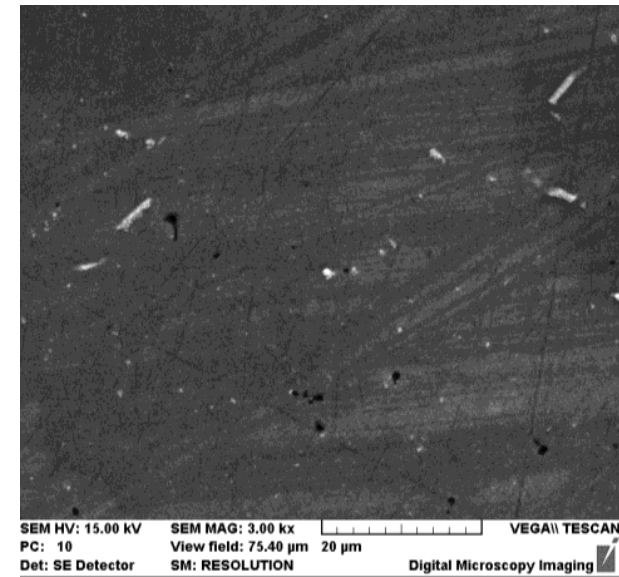

$\sigma$

Рис. 10. Электронно-микроскопические снимки поверхности стали ШХ-15 после полирования: $a$ - твердым раствором оксидов алюминия и железа; $\sigma$ - карбидом бора

Финишное полирование твердым раствором оксидов алюминия и железа основано на окислении поверхности металла. В результате трения при наличии химически активного абразивного материала и окружающей среды имеет место почти мгновенное окисление поверхностного слоя и образование оксидной пленки, которая разрушается и удаляется с поверхности. Высшая степень окисления титана возможна в контактных точках, где образуются микротрещины. В результате окисления и разрушения и удаления пленки шлифуется поверхность.

На рис. 11 приведены SEM - изображение полированной поверхности меди M-1 (a); характеристики ACM: изображение рельефа (б); сечение поверхности: $R_{a} 0,006$ мкм (в); характеристика АСМ изображение полированной поверхности рельефа латуни Л-63 (2).

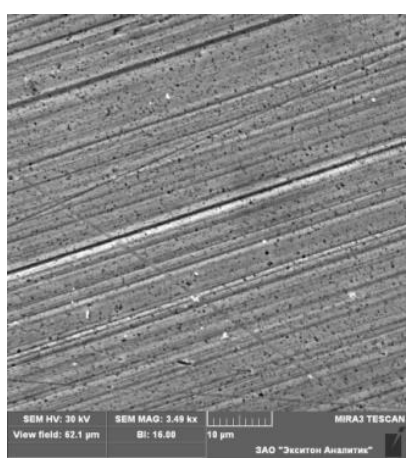

$a$

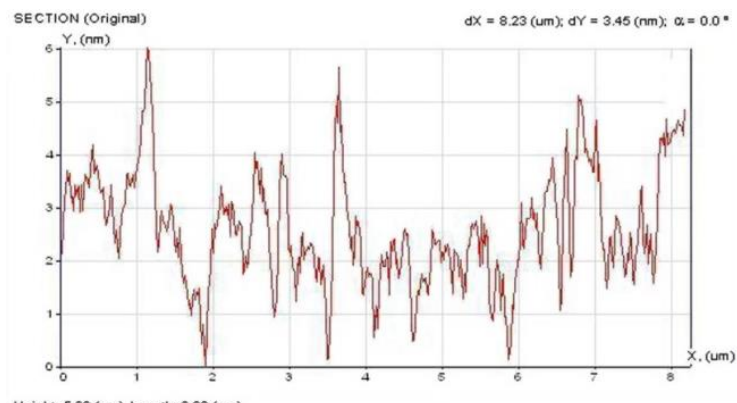

B

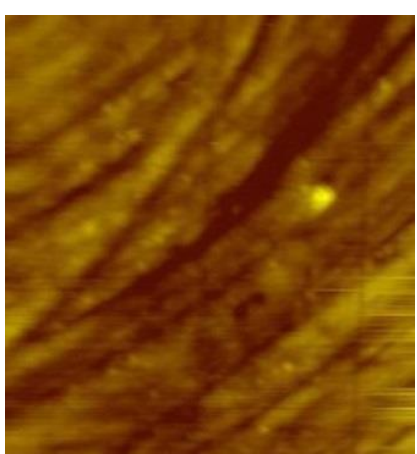

$\sigma$

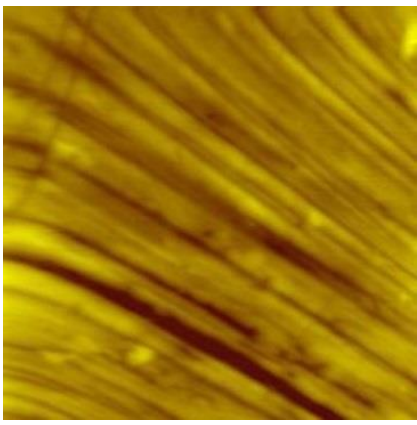

2

Рис.11 Электронно-микроскопическое изображение полированной поверхности меди М-1, характеристики АСМ меди М-1 и латуни Л-63, сечение поверхности меди 
На рис. 12 приведены данные оптической профилометрии полученных полированием образцов титана ВТ1-00.

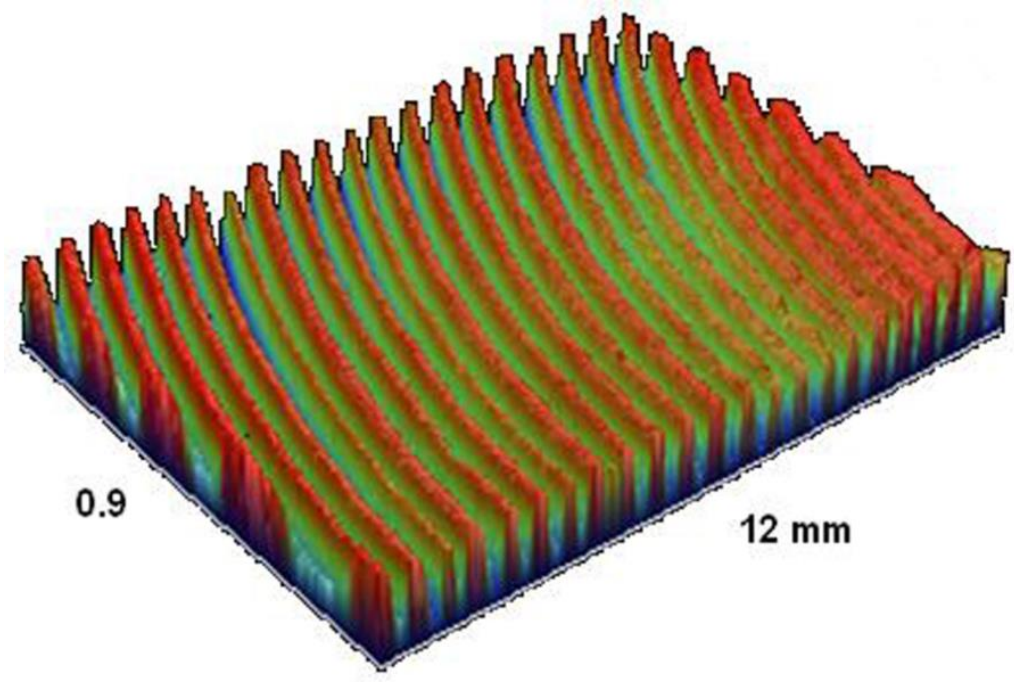

$a$

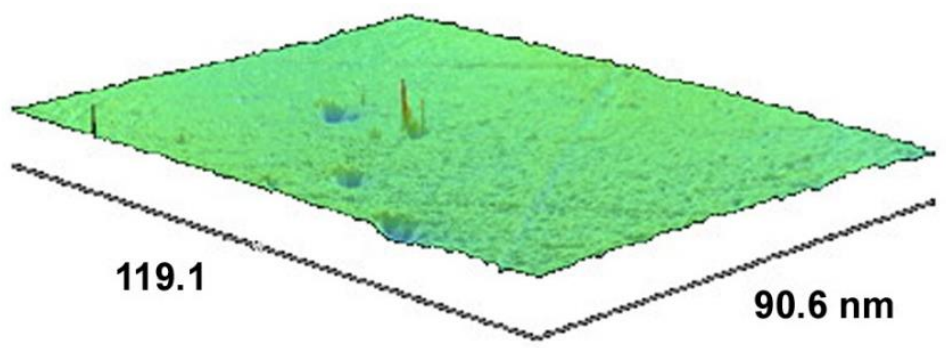

$\sigma$

Рис.12. Полирование титана ВТ1-00: топография поверхности титана образцов: $a$ - первоначальная шероховатость поверхности, $R_{a} 1,3-1,6$ мкм; $\sigma$ - характерное изображение рельефа поверхности образцов, полированных в течение 60 мин, $R_{a} 0,019$ мкм (выборка $161,85 \mathrm{~nm}, \mathrm{~S}^{2} 1,51$ )

Наблюдается определенная закономерность влиянии модифицирования и соотношения микротвердости абразивного материала и микротвердости металлов на полирующую способность (рис. 13). В табл. 3 приведены данные по соотношению микротвердостей абразива и металлов: если это соотношение меньше чем 1,8 ( $\mathrm{HVa} / \mathrm{HVm} \leq 1,8)$, механизм полирования в большей степени является механохимическим.

Известны различные методы получения наночастиц порошкового материала на основе оксида алюминия, например методом импульсного нагрева, однако использовать для полирования такой материал не рекомендуется, поскольку он не обладает необходимыми абразивными свойствами: частицы имеют несформированную кристаллическую структуру [33-36]. Методы, основанные на получении золь-геля гидроксидов переходных металлов с последующим прокаливанием, не дают трибохимического эффекта при полировании, так как в процессе трибохимического активирования играет роль не только наноразмер частиц, но и то, из каких комплексов были получены оксиды [37]. Получение наночастиц абразивного материала методом самораспространяющегося высокотемпературного синтеза (CBC) или механохимическим методом не обеспечивает всего комплекса свойств, необходимых для достижения высокого класса чистоты обработки поверхности $[38,39]$. 


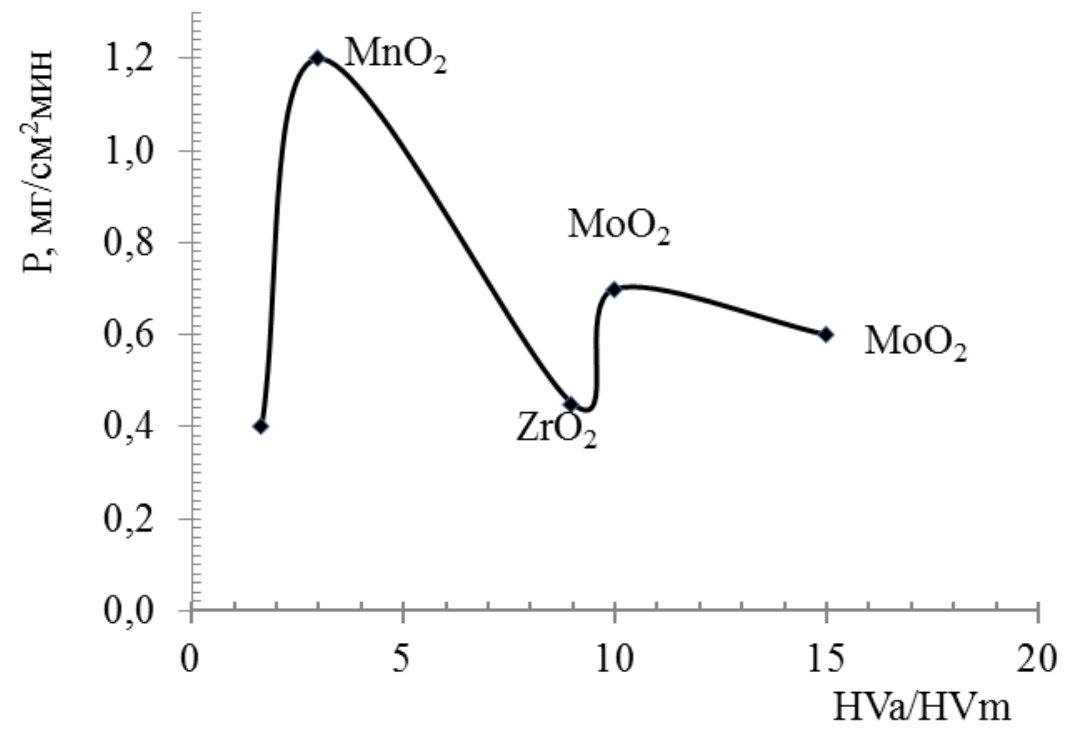

Рис. 13. Зависимость полирующей способности Р (мг/см² мин) от модифицирования твердого раствора оксидов и соотношения микротвердости абразива к микротвердости металла ( $\mathrm{HVa} / \mathrm{HVm})$

Таблица 3 - Соотношение твердости абразива и микротвердости металла и механизм процесса

\begin{tabular}{|c|c|c|c|}
\hline Материал & Абразив & $\begin{array}{c}\text { Соотношение микро } \\
\text { твердостей (МПа) HV. } \\
\text { Абразив/полируемый материал }\end{array}$ & $\begin{array}{c}\text { Механизм } \\
\text { полирования }\end{array}$ \\
\hline Сталь ШХ-15 & Карбид бора & $40000 / 10000=4$ & Абразивный \\
\hline Сталь ШХ-15 & Корунд $\mathrm{Al}_{2} \mathrm{O}_{3}$ & $18000 / 10000=1,8$ & $-"-$ \\
\hline Сталь ШХ-15 & $\begin{array}{c}\mathrm{Al}_{2-\mathrm{x}} \mathrm{Fe}_{\mathrm{x}} \mathrm{O}_{3} \text { и } \mathrm{Fe}_{2-\mathrm{y}} \mathrm{Al}_{\mathrm{y}} \mathrm{O}_{3} \\
\text { нанодисперсный }\end{array}$ & $\begin{array}{c}x / 10000 \leq 1,5 \\
x \leq 1650\end{array}$ & $\begin{array}{l}\text { Трибохимическое } \\
\text { взаимодействие }\end{array}$ \\
\hline Медь М-1 & Сурик $\mathrm{Fe}_{3} \mathrm{O}_{4}$ & $1100 / 1300=0,85$ & \\
\hline Латунь & Крокус $\mathrm{Fe}_{2} \mathrm{O}_{3}$ & $1100 / 1500=0,73$ & \\
\hline Медь М-1 & $\begin{array}{c}\mathrm{Al}_{2-\mathrm{x}} \mathrm{Fe}_{\mathrm{x}} \mathrm{O}_{3} \text { и } \mathrm{Fe}_{2-\mathrm{y}} \mathrm{Al}_{\mathrm{y}} \mathrm{O}_{3} \\
\text { нанодисперсный }\end{array}$ & $\begin{array}{c}x / 1100 \leq 1,5 \\
x \leq 1650\end{array}$ & $\begin{array}{l}\text { Трибохимическое } \\
\text { взаимодействие }\end{array}$ \\
\hline Алюминий & $\begin{array}{c}\mathrm{Al}_{2-\mathrm{x}} \mathrm{Fe}_{\mathrm{x}} \mathrm{O}_{3} \text { и } \mathrm{Fe}_{2-\mathrm{y}} \mathrm{Al}_{\mathrm{y}} \mathrm{O}_{3} \\
\text { нанодисперсный }\end{array}$ & $\begin{array}{c}x / 2000 \leq 1,5 \\
x \leq 1650\end{array}$ & $-"$ \\
\hline
\end{tabular}

К одному из перспективных методов получения наночастиц следует отнести метод химической модификации слоистых структур, где используется образование гидроксокомплексов $\mathrm{M}_{1-\mathrm{x}}^{2+} \mathrm{M}_{\mathrm{x}}^{3}(\mathrm{OH})_{2}\left(\mathrm{X}^{\mathrm{n}-}\right)_{\mathrm{x} / \mathrm{n}} \cdot \mathrm{mH}_{2} \mathrm{O}$. Рассмотрим особенности этого метода. Структура таких соединений состоит из положительно заряженных гидроксидных слоев $\mathrm{M}_{1-\mathrm{x}}^{2+}$ $\mathrm{M}_{\mathrm{x}}^{3}(\mathrm{OH})_{2}^{\mathrm{x}+}$ и анионов $\mathrm{X}^{\mathrm{n}-}$. Для получения нанодисперсных твердых растворов оксидов был использован метод синтеза из гидроксокарбонатных комплексов. При этом совокупность образования промежуточных гидроксокарбонатных комплексных соединений с последующим гидролизом и термогидролизом дает эффект получения качественно новых функцио- 
нальных свойств. Необходимая структура связей формируется на первом этапе - стадии осаждения и образования гидроксокомплексов. Значительное преимущество этого метода неограниченная возможность варьирования атомного соотношения элементов в процессе осаждения.

В результате осаждения на первой стадии (данные ИК-спектроскопии и химического метода анализа) происходит образование аммонийных гидроксокарбонатов алюминия, железа. В состав входят пять гидроксо-групп и две карбоксо-группы и могут быть представлены формулой: $\mathrm{NH}_{4} \mathrm{FeAl}_{2}(\mathrm{OH})_{5}\left(\mathrm{CO}_{3}\right)_{2} \times \mathrm{nH}_{2} \mathrm{O}$. Подобными по составу являются аммонийные гидроксокарбонаты кобальта, алюминия и хрома, исследованные в [40]. Суммарную реакцию осаждения гидроксокарбонатов алюминия и железа можно представить следующим образом [12]:

$$
\mathrm{FeSO}_{4}+\mathrm{Al}_{2}\left(\mathrm{SO}_{4}\right)_{3}+9 \mathrm{NH}_{4} \mathrm{HCO}_{3}=4 \mathrm{NH}_{4} \mathrm{FeAl}_{2}(\mathrm{OH})_{5}\left(\mathrm{CO}_{3}\right)_{2}+4\left(\mathrm{NH}_{4}\right)_{2} \mathrm{SO}_{4}+2 \mathrm{H}_{2} \mathrm{O}+7 \mathrm{CO}_{2} .
$$

Уравнение реакции синтеза твердых растворов путем разложения гидроксокарбонатов следующее:

$$
4 \mathrm{NH}_{4} \mathrm{FeAl}_{2}(\mathrm{OH})_{5}\left(\mathrm{CO}_{3}\right)_{2}+\mathrm{O}_{2}=2 \mathrm{Fe}_{2} \mathrm{O}_{3}+4 \mathrm{Al}_{2} \mathrm{O}_{3}+4 \mathrm{NH}_{3}+8 \mathrm{CO}_{2}+12 \mathrm{H}_{2} \mathrm{O} .
$$

Начало образования фазы твердого раствора оксида алюминия и железа на основе корунда и гематита отмечается при температуре $950-1000{ }^{\circ} \mathrm{C}$, что подтверждается данными DTA и РФА. В процессе термообработки гидроксокарбонатов происходит окисление двухвалентного железа до трехвалентного, что подтверждается данными химического анализа.

В результате изотермической выдержки происходит образование двух твердых растворов ромбоэдрической модификации с пространственной группой $\mathrm{R}-3 \mathrm{c}: \alpha-\mathrm{Al}_{2-\mathrm{x}} \mathrm{Fe}_{\mathrm{x}} \mathrm{O}_{3}-$ дифракционные линии (012), (104), (110), (116) и $\alpha-\mathrm{Fe}_{2-y} \mathrm{Al}_{\mathrm{y}} \mathrm{O}_{3}$ - линии (104), (110), (116).

Для повышения окислительной способности абразивного материала в процессе осаждения вводили молибдат-ионы в виде $0,1 \mathrm{M}$ раствора $\left(\mathrm{NH}_{4}\right)_{6} \mathrm{Mo}_{7} \mathrm{O}_{24}$. Концентрацию оксида железа варьировали в интервале $0,12-0,175$ мол. \%, концентрацию диоксида молибдена 0,001 - 0,005 мол. \%. Оптимальная температура прокалки для получения высокой полирующей способности $1150-1200{ }^{\circ} \mathrm{C}$. При осаждении происходит восстановление $\mathrm{Mo}^{6+}$ до Мо $5,7+$ по реакции [41]:

$$
2 \mathrm{FeSO}_{4}+\left(\mathrm{NH}_{4}\right)_{6} \mathrm{Mo}_{7} \mathrm{O}_{24}+\mathrm{H}_{2} \mathrm{O}=\mathrm{Fe}_{2}\left(\mathrm{SO}_{4}\right)_{2}(\mathrm{OH})_{2}+\left(\mathrm{NH}_{4}\right)_{6} \mathrm{Mo}_{7} \mathrm{O}_{23} .
$$

В результате термообработки происходит разложение молибдата аммония со степенью окисления $+5,7$ с образованием диоксида молибдена тетрагональной модификации по реакции:

$$
\left(\mathrm{NH}_{4}\right)_{6} \mathrm{Mo}_{7} \mathrm{O}_{23}=6 \mathrm{NH}_{3}+7 \mathrm{MoO}_{2}+3 \mathrm{H}_{2} \mathrm{O}+3 \mathrm{O}_{2} .
$$

Образование тетрагонального диоксида молибдена $\mathrm{MoO}_{2}$ с пространственной группой P42/mnm - линии $h k l$ (110), (200), (211) - с параметрами решетки, близкими к параметрам диоксида марганца той же модификации. Схема реакций синтеза следующая:

$$
\begin{gathered}
\mathrm{NH}_{4} \mathrm{Al}_{2} \mathrm{Fe}(\mathrm{OH})_{5}\left(\mathrm{CO}_{3}\right)_{2}+\left(\mathrm{NH}_{4}\right)_{6} \mathrm{Mo}_{7} \mathrm{O}_{24} \rightarrow \mathrm{NH}_{4} \mathrm{Al}_{2} \mathrm{Fe}(\mathrm{OH})_{6}\left(\mathrm{CO}_{3}\right)_{2}+ \\
+\mathrm{NH}_{4} \mathrm{Al}_{2} \mathrm{Fe}(\mathrm{OH})_{5}\left(\mathrm{CO}_{3}\right)_{2}+\left(\mathrm{NH}_{4}\right)_{6} \mathrm{Mo}_{7} \mathrm{O}_{23} \stackrel{220 \div 250{ }^{\circ} \mathrm{C}}{\longrightarrow} \mathrm{Al}_{2} \mathrm{Fe}(\mathrm{OH})_{4} \mathrm{O}_{2} \stackrel{425 \div 450{ }^{\circ} \mathrm{C}}{\longrightarrow} \\
\rightarrow \mathrm{Al}_{2} \mathrm{O}_{3} * \mathrm{Fe}_{2} \mathrm{O}_{3 \text { аморф }}+\mathrm{Fe}_{2} \mathrm{O}_{3 \text { крист }} \stackrel{950 \div 1150{ }^{\circ} \mathrm{C}}{\longrightarrow} \mathrm{Al}_{2-\mathrm{x}} \mathrm{Fe}_{\mathrm{x}} \mathrm{O}_{3 \text { крист }}+ \\
+\mathrm{Fe}_{2-\text { у }} \mathrm{Al}_{\mathrm{y}} \mathrm{O}_{3 \text { крист }}+\mathrm{MoO}_{2 \text { крист }}
\end{gathered}
$$


Процесс образования твердого раствора оксидов алюминия и железа из гидроксокарбонатных комплексов с введением добавки молибдат-ионов влияет на абразивные свойства материала. Присутствие в образцах $\mathrm{MoO}_{2}$ в количестве $0,001-0,005$ мол. \% увеличивает полирующую способность в 6-7 раз при полировании меди и латуни, что отражено на кинетических кривых (рис. 7). Наиболее высокой полирующей способностью обладают образцы, содержащие 0,15-0,18 мол. \% $\mathrm{Fe}_{2} \mathrm{O}_{3}$, при мольном соотношении корунда и гематита 4:1. Получение наименьшей шероховатости поверхности $\mathrm{R}_{\mathrm{a}} 0,002$ мкм отмечается с применением образцов, содержащих оксид железа в интервале 0,125-0,156 мол. \%.

В случае модифицирования диоксидом циркония на второй стадии в процессе твердофазного синтеза при термообработке гидроксокарбонатов в интервале температур от 950 до $1150{ }^{\circ} \mathrm{C}$ происходит окисление двухвалентного железа до трехвалентного и образование твердых растворов оксидов алюминия и железа, а также модифицирующих диоксидов циркония, что подтверждается данными рентгенофазового и химического методов анализа. Уравнения реакции образования твердых растворов оксидов следующие [42]:

$$
\begin{gathered}
2 \mathrm{ZrOSO}_{4}+6 \mathrm{NH}_{4} \mathrm{HCO}_{3}=\left(\mathrm{NH}_{4}\right)_{2} \mathrm{Zr}_{2} \mathrm{O}_{2}(\mathrm{OH})_{2}\left(\mathrm{CO}_{3}\right)_{2}+4 \mathrm{CO}_{2}+2 \mathrm{H}_{2} \mathrm{O}+2\left(\mathrm{NH}_{4}\right)_{2} \mathrm{SO}_{4} \\
4 \mathrm{NH}_{4} \mathrm{FeAl}_{2}(\mathrm{OH})_{5}\left(\mathrm{CO}_{3}\right)_{2}+\mathrm{O}_{2}=2 \mathrm{Fe}_{2} \mathrm{O}_{3}+4 \mathrm{Al}_{2} \mathrm{O}_{3}+4 \mathrm{NH}_{3}+8 \mathrm{CO}_{2}+12 \mathrm{H}_{2} \mathrm{O} \\
\left(\mathrm{NH}_{4}\right)_{2} \mathrm{Zr}_{2} \mathrm{O}_{2}(\mathrm{OH})_{2}\left(\mathrm{CO}_{3}\right)_{2}=2 \mathrm{ZrO}_{2}+2 \mathrm{CO}_{2}+2 \mathrm{H}_{2} \mathrm{O}+2 \mathrm{NH}_{3} .
\end{gathered}
$$

В общем виде:

$$
\begin{gathered}
\mathrm{NH}_{4} \mathrm{Al}_{2} \mathrm{Fe}(\mathrm{OH})_{5}\left(\mathrm{CO}_{3}\right)_{2}+\left(\mathrm{NH}_{4} \mathrm{Zr}_{2} \mathrm{O}_{2}(\mathrm{OH})_{2}(\mathrm{CO} 3)_{2} \rightarrow \mathrm{Al}_{2} \mathrm{Fe}(\mathrm{OH})_{4} \mathrm{O}_{2}+\mathrm{Zr}_{2} \mathrm{O}_{2}(\mathrm{OH})_{2} \rightarrow\right. \\
\rightarrow \mathrm{Al}_{2} \mathrm{O}_{3} \cdot \mathrm{Fe}_{2} \mathrm{O}_{3 \text { amorp }}+\mathrm{ZrO}_{2 \text { amorp }} \rightarrow \mathrm{Al}_{2-\mathrm{x}} \mathrm{Fe}_{\mathrm{x}} \mathrm{O}_{3 \text { cryst }}+\mathrm{ZrO}_{2 \text { cryst }} .
\end{gathered}
$$

Отмечается образование твердого раствора оксидов алюминия и железа ромбоэдрической модификации с пространственной группой $R-3 c: \alpha-\mathrm{Al}_{2-\mathrm{x}} \mathrm{Fe}_{\mathrm{x}} \mathrm{O}_{3}(85,9$ мас. \%) - дифракционные линии (012), (104), (110), (116), $\alpha-\mathrm{Fe}_{2} \mathrm{O}_{3}$ (7,7 мас. \% ) - линии $h k l$ (012), (104), (110), (116), а также образование тетрагонального диоксида циркония (1,9 мас. \%) с пространственной группой $P 42 / n m c$ - линии $h k l$ (101) (110), (112), и моноклинного (3,7 мас. \% ) диоксида циркония с пространственной группой $R 21 / c$ - линии $h k l(011)(\overline{1} 11),(111)$. Дополнительно образуется орторомбический $\mathrm{AlFeO}_{3} 3,7$ мас. \% с пространственной группой Pna21 линии $h k l$ (011), (111), (022), (122). Химический рентгенофлюоресцентный энергодисперсионный анализ дает следующий состав: $\mathrm{Al}_{2} \mathrm{O}_{3}-70,0 \% ; \mathrm{Fe}_{2} \mathrm{O}_{3}-25,0 \% ; \mathrm{ZrO}_{2}-5,0 \%$, что хорошо совпадает с данными РФА.

Данные, полученные в результате исследований седиментации (рис. 14) и электронной микроскопии, показывают, что образцы твердых растворов оксидов алюминия и железа (моль 0,12 до $0,156 \% \mathrm{Fe}_{2} \mathrm{O}_{3}$ и $0,04-0,08$ моль \% $\mathrm{ZrO}_{2}$ ) содержат наночастицы: основная часть - это частицы размером 50 нм. Образцы с концентрацией 0,08 моль \% $\mathrm{ZrO}_{2}$ содержат наночастицы, более чем на 50 нм. Образцы содержат также наночастицы до 10 нм, которые собираются в более крупные частицы за счет электростатического притяжения. Но эти частицы быстро распадаются на мелкие наночастиц, поэтому в процесс полирования не оставляют царапин на поверхности образца. 


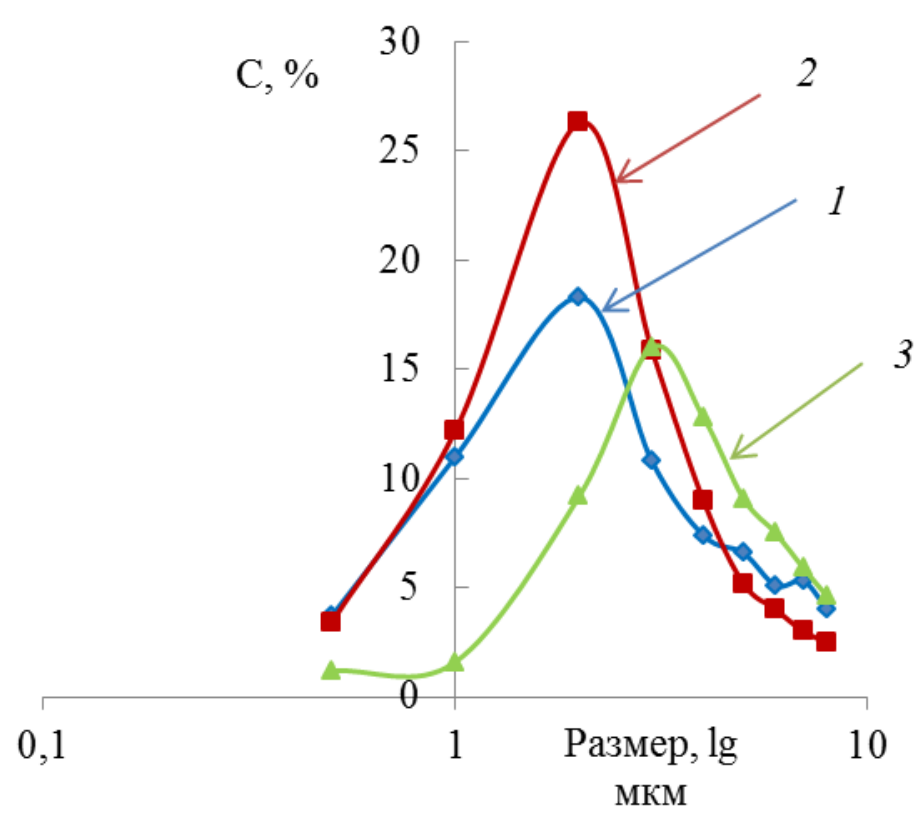

Рис. 14. Дифференциальные кривые распределения частиц для сложных оксидов алюминия и железа: 1 - немодифицированные; 2 - модифицированные с 0,004 мол. \% $\mathrm{ZrO}_{2}$; 3 - модифицированные с 0,008 мол. $\% \mathrm{ZrO}_{2}$

\section{4. Заключение}

Таким образом, финишное полирование металлов с трибохимически активными материалами представляет механохимический процесс, в котором происходит механическая активация поверхности металла, сопровождающаяся окислением поверхности металла и образованием оксидной пленки, затем ее разрушением и удалением. Скорость полирования зависит от трибохимической активности абразивного материала. Так как полирование является процессом на границе твердых тел, включающим окисление и образование оксидной фазы в подповерхностном слое, то всю систему правомерно рассматривать как двухфазную с разделяющей поверхностью, расположенной между объемной и поверхностной фазами металла с обменом ионами и химическим равновесием. Такие процессы относятся к топохимическим, и для описания кинетики полирования с участием реакций в подповерхностном слое можно применить уравнение Ерофеева-Колмогорова. Установлено, что получаемый из гидроксокомплексов твердый раствор оксидов алюминия и железа на основе корунда и гематита $\left(\mathrm{Al}_{2-\mathrm{x}} \mathrm{Fe}_{\mathrm{x}} \mathrm{O}_{3}\right.$ и $\left.\mathrm{Fe}_{2-\mathrm{y}} \mathrm{Al}_{\mathrm{y}} \mathrm{O}_{3}\right)$, является трибохимически активным, обеспечивает высокую производительность и наношероховатость поверхности $\left(R_{a} 0,005-0,002\right.$ мкм) в процессах финишного полирования стали с аустенитно-мартенситной структурой типа марки ШХ-15, а также меди, алюминия и титана и их сплавов. Для получения шероховатости поверхности $R_{a}$ менее 0,005 мкм абразивный материал содержит нанодисперсные фракции, способные участвовать в трибохимических реакциях. Для увеличения производительности полирования цветных металлов необходимо модифицирование твердых растворов оксидов алюминия и железа оксидами молибдена, марганца и циркония.

\section{Благодарность}

Автор выражает признательность и благодарность к.х.н. А. П. Тютюнник, ведущему научному сотруднику Института химии твердого тела Уральского отделения Российской академии наук за проведенный рентгенофазовый анализ образцов оксидов.

В эксперименте было использовано оборудование и приборы Центра Коллективного Пользования (ЦКП) Института машиноведения Уральского отделения Российской академии наук. 


\section{Литература}

1. Artemov A. S. Polishing nanodiamonds // Physics of the Solid State. - 2004. - Vol. 46, iss. 4. - P. 687-695. - DOI: 10.1134/1.1711453.

2. Jackson M. J., Mills B., Hitchiner M. P. Controlled wear of vitrified abrasive materials for precision grinding applications // Sadhana. - 2003. - Vol. 28, no. 5. - P. 897-914.

3. Bakharev V. P. Dispersion of Ceramics and Composites in Diamond Finishing by Free Abrasive // Russian Engineering Research. - 2009. - Vol. 29, no. 2. - P. 162-168. DOI: $10.3103 / \mathrm{S} 1068798 X 09020129$.

4. Assessment of surface roughness and reflectance of nonmetallic products upon diamond abrasive finishing / Yu. D. Filatov, V. P. Yashchuk, U. Heisel, M. Storchak, G. Monteil // Journal of Superhard Materials. - Vol. 31, no. 5. - P. 338-346. - DOI: 10.3103/S1063457609050098.

5. Storozhenko P. A., Guseinov S. L., Malashin S. I. Nanodispersed powders: Synthesis methods and practical applications // Nanotechnologies in Russia. - 2009. - Vol. 4, iss. 5. - P. 27-39. DOI: $10.1134 / \mathrm{S} 1995078009050024$.

6. Pokropivnyi V. V, Silenko P. M. Silicon carbide nanotubes and nanotubular fibers: Synthesis, stability, structure, and classification // Theoretical and Experimental Chemistry. - 2006. Vol. 42, iss 1. - P. 3-15. - DOI: 10.1007/s11237-006-0010-y.

7. Khanra A. K. Production of boron carbide powder by carbothermal synthesis of gel material // Bull. Mater. Sci. - 2007. - Vol. 30, iss. 2. - P. 93-96. - DOI: 10.1007/s12034-007-0016-7.

8. Bogdanov S. P. Influence of superstoichiometric boron on the Synthesis of cubic Boron nitride // Glass Physics and Chemistry. - 2008. - Vol. 34, no. 3. - P. 336-339. DOI: $10.1134 / \mathrm{S} 108765960802017 \mathrm{X}$.

9. Гаршин А. П., Гропянов В. М., Лагунов Ю. В. Абразивные материалы. - Л. : Машиностроение, 1983. - 230 с.

10. Viktorov V. V., Fotiev A. A., Badich V. D. Abrasive and thermal properties of $\mathrm{Al}_{2} \mathrm{O}_{3}-\mathrm{Cr}_{2} \mathrm{O}_{3}$ solid solutions Абразивные и термические свойства твердых растворов системы $\mathrm{Al}_{2} \mathrm{O}_{3}-\mathrm{Cr}_{2} \mathrm{O}_{3} / /$ Inorganic Materials. - 1996. - Vol. 32, iss. 1. - P. 55-57.

11. Chekhomova L. F. Abrasive Properties of Modified Chromia // Inorganic Materials. - 2001. Vol. 37, no. 3. - P. 274-280. - DOI: 10.1023/A:1004173632509. - ISSN 0020-1685.

12. Chekhomova L. F. Abrasive properties of aluminum iron oxide nanoparticles // Inorganic Materials. - 2009. - Vol. 45., no. 10. - C. 1158-1165. - DOI: 10.1134/S0020168509100148.

13. Ходаков Г. С. Физико-химическая механика технологических процессов обработки материалов // Рос. хим. журн. им. Д. И. Менделеева. - 2000. - № 3. - С. 93-107.

14. Марченко Е. А., Харач Г. М. О закономерностях образования микротрещин в поверхностных слоях металлов в условиях трения при пластическом контакте // Доклады Академии наук СССР. Техническая физика. - 1976. - Т. 231. - № 4. - С. 853-855.

15. Ящерицын П. И., Мартынов А. Н. Чистовая обработка деталей в машиностроении. Минск. - Вышэйшая школа. - 1983. - 191 с.

16. Кубашевский О., Гопкинс Б. Окисление металлов и сплавов. - М. : Металлургия. 1965. - $428 \mathrm{c}$.

17. Pad Effects on Material-Removal Rate in Chemical - Mechanical Planarization / A. F. Bastawtos, A. Chandra, Y. Guo, B. Yan // Journal of Electronic Materials. - 2002. Vol. 31, no. 10. - C. 1022-1031. - DOI: 10.1007/s11664-002-0038-2.

18. Tseng W-T., Wang Y-H., Chin J-H. Effects of film stress on the chemical mechanical polishing process // Journal of the Electrochemical Society. - 1999. - Vol. 146, iss. 11. P. 4273-4280. - DOI: 10.1149/1.1392627.

19. Fu G., Chandra A. A model for wafer scale variation of material removal rate in chemical mechanical polishing based on viscoelastic pad deformation // Journal of Electronic Materials. 2002. - Vol. 31, no. 10. - P. 1066-1073. - DOI: 10.1007/s11664-002-0044-4. 
20. Fu G., Chandra A. A model for wafer scale variation of removal rate in chemical mechanical polishing based on elastic pad deformation // Journal of Electronic Materials. - 2001. - Vol. 30, no. 4. - P. 400-408. - DOI: 10.1007/s11664-001-0051-X.

21. Wang Y. G., Zhao Y. W., Li X. Modeling the effects of abrasive size, surface oxidizer and binding energy on chemical mechanical polishing at molecular scale // Tribology International. 2008. - Vol. 41. - P. 202-210. - DOI: 10.1016/J.Triboint.2007.08.004.

22. Х Хайнике Г. Трибохимия. - М. : Мир, 1987. - 582 с.

23. Ребиндер П. А. Значение физикохимических процессов при механическом разрушении и обработке твердых тел в технике // Вестник АН СССР. - 1940. - № 8. - С. 5-28.

24. Лихтман И., Щукин Е. Д., Ребиндер П. А. Физико-химическая механика металлов. М. : Изд. АН СССР. - 1962. - 303 с.

25. Мамонова М. В., Прудников В. В., Прудникова И. А. Физика поверхности. Теоретические модели и экспериментальные методы. - М. : Физматлит. - 2011. - 400 с. ISBN 978-5-9221-1236-9.

26. Тонкие пленки. Взаимная диффузия и реакции / Под ред. Дж. Поута, К. Ту, Дж. Мейера. - М. : Мир. - 1982. - 575 с.

27. Cabrera N. The oxidation of metals // Semiconductor surface physics. - Philadelphia : Univ. of Pennsylvania Press, 1956. - P. 327-332.

28. Mott N. The theory of protective films formation on the metal surface // Trans. Faraday Soc. 1949. - Vol. 40. - P. 472-486.

29. Koroleva L. F. Final Polishing of Metals to Obtain Nanoroughened Surface // Nanotechnologies in Russia. - 2012. - Vol. 7, nos. 1-2. - P. 67-75. - DOI: 10.1134/S1995078012010119. ISSN: 1995-0780.

30. Болдырев В. В. Реакционная способность твердых веществ (на примере реакции термического разложения). - Новосибирск : Изд. СО РАН. - 1997. - 304 с.

31. Сакович Г. В., Чижова Н. П. Температурная зависимость скорости термического разложения бикарбоната калия // Изв. ВУЗов. Химия и хим. технология. - 1961. - № 5. C. 747-750.

32. Kim Jin-seob, Lim Eun-seong, Jung Yoon-gyo. Determination of efficient superfinishing conditions for mirror surface finishing of titanium // J. Cent. South Univ. - 2012. - Vol. 19. P. 155-162. - DOI: 10.1007/s11771-012-0985-6. - ISSN: 2095-2899.

33. Котов Ю. А., Саматов О. М. Характеристики порошков оксида алюминия, полученных импульсным нагревом проволоки // Поверхность. - 1994. - № 10-14. - С. 90-94.

34. Separation of aluminum oxide powders with different degrees of aggregation by sedimentation in an aqueous medium / A. P. Safronov, E. G. Kalinina, D. A. Blagodetelev, Y. A. Kotov // Nanotechnologies in Russia. - 2010. - Vol. 5, iss. 7-8. - P. 498-505. DOI: $10.1134 /$ S1995078010070104.

35. Силяков Л., Песоцкая Н. С., Юхвид В. И. Самораспространяющийся высокотемпературный синтез и свойства абразивного композиционного материала на основе корунда // Неорган. материалы. - 1995. - Т. 31, № 3. - С. 351-357.

36. Tarasov A. G., Gorshkov V. A., Yukhvid V. Phase composition and microstructure of $\mathrm{Al}_{2} \mathrm{O}_{3}-\mathrm{Cr}_{2} \mathrm{O}_{3}$ solid solutions prepared by self-propagating high-temperature synthesis // Inorganic Materials. - Vol. 43, iss. 7. - P. 724-728. - DOI: 10.1134/S0020168507070102.

37. A sol-gel method for synthesizing porous iron-aluminum oxide substances and regulating their physicochemical characteristics / V. M. Belousov, V. M. Chertov, E. V. Rozhkova, V. I. Litvin, V. A. Zazhigalov // Theoretical and Experimental Chemistry. - 1997. - Vol. 33, no. 2. P. 103-105. - DOI: 10.1007/BF02765955.

38. СВС-абразивы. Производство. Свойства. Применение / А. Г. Мержанов, И. П. Боровинская, В. К. Прокудина, Н. С. Песоцкая, М. А. Насонова // Наука призводству. 1998. - № 8 (10). - C. 4-12. 
39. Tsuzuki T., Mccormick P. G. Synthesis of $\mathrm{Cr}_{2} \mathrm{O}_{3}$ nanoparticles by mechanochemical processing // Acta Mater. - 2000. - Vol. 48, no. 11. - P. 2795-2801. - DOI: 10.1016/S03048853(99)00064-5.

40. Koroleva (Chekhomova) L. F. Synthesis of Spinel-Based Ceramic Pigments from Hydroxycarbonates // Glass and Ceramics. - 2004. - Vol. 61, nos. 9-10. - P. 299-302. DOI: 10.1023/B:GLAC.0000048695.24873.a9. - ISSN 0361-7610.

41. Koroleva L. F. Synthesis and abrasive properties of nanoparticulate $\mathrm{MoO}_{2}$-modified $\mathrm{Al}_{2-\mathrm{x}} \mathrm{Fe}_{\mathrm{x}} \mathrm{O}_{3}$ and $\mathrm{Fe}_{2-\mathrm{y}} \mathrm{Al}_{\mathrm{y}} \mathrm{O}_{3}$ solid solutions // Inorg. Materials. - 2010. - Vol. 46, no 12. - P. 13301336. - DOI: 10.1134/S0020168510120113. - ISSN 0020-1685.

42. Koroleva L. F. Nanoparticulate zirconia-modified solid solutions of aluminum-iron oxides for polishing titanium metal // Diagnostics, Resource and Mechanics of materials and structure. 2015. - Iss. 1. - P. 90-102. - DOI: 10.17804/2410-9908.2015.1.090-102. URL: http://dreamjournal.org. 